\title{
A Review of Interfirm Networks: A Deeper Understanding of the Relationships Paradigm
}

\author{
Jie G. Fowler \\ Valdosta State University • Valdosta, Georgia \\ Timothy H. Reisenwitz \\ Valdosta State University • Valdosta, Georgia
}

\section{Abstract}

Interfirm relationships or networks take a variety of forms and can potentially provide significant synergy for the participants. Yet, most of research studies, to date, have primarily analyzed interfirm networks based upon one paradigm/ perspective. This review aims to examine a complete theoretical basis of network research and looks for research gaps and practical implications for both researchers and practitioners. Specifically, it summarizes six conceptual perspectives regarding interfirm networks: motivational, relational, structural, evolutionary, interactional, and governance, in order to address similarities and differences among different perspectives. With this purpose in mind, the relevant literature is reviewed and, at the conclusion of each conceptual perspective, areas of research that require more development and investigation are identified. Finally, suggestions for managers contemplating or engaged in interfirm networks are presented.

\section{Introduction}

The network paradigm originally built upon the notion that economic actions are embedded in a social network of relationships. In essence, organizations can be interconnected with other organizations through a wide array of social networks in order to improve effectiveness and efficiency. For instance, through examining a variety of forms of collaboration, ranging from consortia to joint venture, to franchising, to dealership, Fabrizio (2011) found collaboration among firms of different sizes helps to overcome weaknesses without increasing transitional costs. Other scholars found that firms organized in networks have higher survival chances and that prestigious partners help firms to go to IPO faster (Gulati, Dialdin \& Wang, 2002). In addition, networks may also enable firms to gain access to capital in order to sustain operations and investment, while lower the transitional costs (Khanna \& Rivkin, 2001). For instance, research findings show that network members in China reported higher financial performance and productivity (Keister, 1998). Further, networks may reduce consumer uncertainty attitudes towards the brand. For instance, 
Ingram and Baum's (1997) study of chain affiliation of Manhattan hotels suggests that a hotel that joins a high status hotel chain signals its high status. Recent literature on networks attempted to examine the knowledge transfer among connected firms. For instance, the vertical networks between Toyota and its suppliers and among suppliers themselves facilitate knowledge learning and provide members learning and productivity advantages over non-members (Dyer \& Nobeoka, 2000).

Traditional economic literature identified that a firm has at least three alternatives in order to maintain its strategies, such as searching for suppliers and new markets (Mariti \& Smiley, 1983): the firms have options to develop a cooperative agreement with other firms, firms may make resources available to individual market transactions, and firms may organize themselves internationally. The last two alternatives can illustrated by the technological approach based upon economies and diseconomies of scale and Adam Smith's principle of division of labor---refined and elaborated by Stigler (1951), Coase (1937), and Williamson (1975). However, recent empirical evidence shows that the maxim of "networks matter" may contradict the traditional economics of scope/scale and successful exploitation of personal or organizational relationships is essential for firms to gain and maintain competitive advantages (Khoja, 2010). As such, practitioners should be vigilant to develop relationships in networks.

By definition, a network describes a collection of actors (e.g., persons, divisions, firms, countries) and their connections (Iacobucci, 1996; Thorelli, 1986). Brass, Galaskeiwica, Greve, and Tsai (2004) define a network as "a set of nodes and the set of ties representing some relationships, or lack of relationships, between the nodes" (p. 481). The ties that connect actors take many different forms. They can be directed (i.e., potentially unidirectional as in giving advice to someone) or undirected (e.g., being physically proximate), and they can be dichotomous (e.g., present or absent) or valued (e.g., the strength of a friendship) (Borgatti \& Foster, 2003). An organizational network is defined as a collection of more than two firms that pursue repeated exchange relationships with one another but lack a legitimate organizational authority to manage the exchange process (Podolny \& Page, 1998). This definition encompasses a wide range of interfirm relations, including alliances, joint ventures, business groups, franchises, and research consortia, while excluding such market arrangements as short term contracts or spot-market transactions. Sydow and Windeler (1998) investigate the properties of interfirm networks, which they consider "as an institutional arrangement among distinct but related for-profit organizations which are characterized by a special kind of network relationship, a certain degree of flexibility, and a logic of exchange that operates differently from 
that of markets and hierarchies" (p. 266). In essence, interfirm networks differ from any interorganizational arrangement of firms at least with respect to the three properties above.

Traditionally, networks have been investigated in connection with other topics, such as sociology. For instance, various sociologists have investigated such topics as embeddedness (Uzzi, 1997), social capital (Portes, 1998), social exchange (Cook, 1977), and structuration theory (Giddens, 1984) in an organizational network context. Increasingly, they have become interesting topics unto themselves in organizational research. Organizational scholars found that economic actions are embedded in social relations and interfirm relations generate and are generated by embedded relations that differ from traditional arm's-length market ties. In marketing and management, over the last three decades, this recognition is reflected in the increase in, and the character of, research on distribution channels, supply chain management, buyer-seller relationships, buying centers, diffusion of innovations, and new product alliances.

As a result, recent expansion of research interest in management and marketing calls for a review and classification of work in interfirm networks. As such, the primary objective of this paper is to review, synthesize, and integrate empirical and conceptual articles on interfirm networks in management and marketing literature and to offer suggestions and direction for researchers and practitioners in this area. We examine the articles in six groupings, based upon what we interpret as one of six primary conceptual perspectives that they reflect: motivation, relational, structural, evolutionalist, interactionalist, and governance.

The following discussion begins with examinations of interfirm network research that reflects each of the previously noted six conceptual perspectives. For each perspective, the literature is reviewed and the research gap in each perspective is identified at the end of each section. ${ }^{1}$

\section{The Motivation Perspective and Research Gaps}

The motivation perspective is concerned with why firms behave in certain ways with respect to the networks. It focuses on two basic questions: why do firms enter into network entities such as alliances, joint ventures and other business groups such as buying groups and trade associations; and why do they make certain strategic choices about relations and interactions with other network members? In general, this body of work is based upon cost factors (transaction costs), internal factors (firm's capabilities, resources-based view), and external influences (social 
capital, institutional-based view) (e.g., Eisenhardt \& Schoonhoven, 1996; Williamson, 1985).

Traditionally, the approach that has been used to understand how strategic alliances form is transaction cost economics (Williamson, 1985). Transaction cost economics emphasizes transaction cost efficiency as a motivation for the corporation to enter into a network (Eisenhardt \& Schoonhoven, 1996). It has been effective in predicting vertical integration among suppliers and buyers in mature industries, such as automobile manufacturing (e.g., Osborn \& Baughn, 1990). However, the logic of transaction costs does not capture many strategic aspects of networks, such as learning, creation of legitimacy, and fast market entry (Eisenhardt \& Schoonhoven, 1996). In order to address the firm's capabilities in forming strategic alliances, Eisenhardt and Schoonhoven began to examine strategic needs as motivation for firms forming alliances and positioning themselves in a network. Such work begins to move beyond transaction costs and looks at logical resource needs and social resource opportunities.

In comparison, the resource-based view of motivation in interfirm networks emphasizes strategic factors and characteristics of the firm rather than transaction costs. Furthermore, this view focuses on the logic of needs rather than efficiency. Many studies on firms' motivations for entering into alliances take a resource-based view. Das and Teng (2000) attempt to relate different resource characteristics (i.e., property-based and knowledge-based resources) to alliance formation and structure. Lee, Lee, and Pennings (2001) further examine the influence of internal capabilities and external networks. Lavie (2006) borrows the notion of network resources (Gulati, 1999) to extend the resource-based view by incorporating network resources of interconnected firms. Lavie (2006) proposes a model that distinguishes shared resources from non-shared resources and reveals how interconnected firms can extract value from resources that are not fully-owned or controlled by the organization.

Another stream of research on firms' motivations employs social capital theory. Scholars who have contributed to social capital theory include Bourdieu (1983, 1986), Burt (1997), Coleman (1988), Lin (1999), Portes (1998), and Putnam (2000). Specifically, social capital theory explains how organizations access and use resources embedded in a social network to gain returns (e.g., seeking economic help). Based upon this theory, organizations are motivated to engage in interaction and networking in order to enhance outcomes (Lin, 1999). Organizational scholars have utilized social capital theory for decades. For instance, Koka and Prescott (2002) suggest that social capital could yield informational benefits for the firm. Lee et al. (2001) argue that the firms' capabilities and social capital interactively influ- 
ence start-up firms' performance in terms of sales growth but that social capital alone has weak main effects on firm performance. In recent years, due to the rising global marketplace, scholars have begun to apply social capital theory to cross-cultural research. For instance, Gu, Huang, and Tse (2008) draw upon social capital theory to examine how firms make strategic choices through guanxi networks in China.

Additionally, a series of studies grounded in the institutional-based view can be used to explain the firm's motivation to make strategic choices as well. Institutional theories (DiMaggio \& Powell, 1983; Scott, 1987) believe that organizational actions are driven by social justification. From this perspective, strategic decisions are social and normatively defined because their motives derive from an actor's propensity to legitimate cooperating activities. Participants in the network believe that their effectiveness is judged by other constituents (e.g., shareholders, customers, suppliers). According to the theory, organizations are motivated to seek legitimacy or approval from those potential constituents. So far, there are only a few scholars who have applied this theory in network research. For instance, Dacin, Oliver, and Roy (2007) examine the legitimating aspect of strategic alliances. Drawing upon an institutional-based view, they argue that the social symbolic and signaling characteristics of alliances serve as a source of legitimacy for partnering, and legitimacy serves as a means to achieve competitive advantage.

As previously mentioned, motivational studies in network research tend to explain why firms enter into networks and why they make certain strategic choices within those networks. The research reviewed thus far highlights many of the theories (transaction cost economics, resource-based view, social capital theory, and the institutional-based view), and each of them emphasizes different aspects of what motivates firms to enter into networks. However, each also tends to ignore or tradeoff other important factors that may lead firms to enter into networks. For instance, transaction cost economics theorists highlight the cost and efficiency but lack explanations of social legitimacy. The resource-based view theorists focus upon firms' capabilities but ignore the cost factor. Additionally, social capital theorists concentrate on social gain and membership but lose sight of stakeholders' capabilities.

Furthermore, while researchers have shown that different theories can explain different kinds of motives, there are no clear boundaries among these theories. For instance, the institutional-based view, which concerns social norms, may potentially overlap with social capital theory in terms of social sanctions and expected reciprocity. The resource-based view may overlap with social capital theory in terms of instrumental return. In general, while a few scholars (e.g., Lee et al., 2001) often acknowledge that there is a need for combining theories when conducting research, 
we believe that examining the commonality and difference between theories can create an outlet for future research.

Finally, though much research has been done in terms of organizational motives to enter into a network, there is a lack of research concerning the retreat or exit from a network. There is a need to investigate the causes/motivations for exiting a strategic network. Factors such as relational conflicts, asymmetric exchange, new partnership formation, relationship maintenance costs, industrial environmental change, and network structure transition need to be examined as well. Such studies will not only inform us as to what motivates firms to exit networks but potentially what motivates firms to enter them.

\section{The Relational Perspective and Research Gaps}

Relational studies represent one of the earliest streams of research related to networks and continue to be of interest to network researchers. In general, the relational perspective is concerned with how aspects of the relationships among networks members - including strength, distance, and other qualities of ties-affect and are affected by other factors, such as member firms' strategic choices, performance, and knowledge creation. Specifically, relational network studies are based upon the relational tie literature, which is primarily concerned with the nature of the relational bond between two or more actors. Scholars in this domain typically classify the relationship between social actors as being linked by weak or strong, instrumental or expressive, and direct or indirect ties. For instance, Larson (1992) shows that strong ties promote or enhance trust, mutual gain, and reciprocity among firms from a long-term perspective. Consequently, partners are likely to form joint problem solving arrangements as well (Powell, 1990; Uzzi, 1996).

Several important studies have clarified, and in some cases modified, the theory of relational ties by extending the research in new directions. Gulati and Westpal (1999) examine how interlocking ties have different effects on the formation of joint ventures between firms. Based upon this finding, the content of ties (direct vs. indirect) can have a strong influence over corporate strategy decisions; some ties may promote the creation of a new alliance, while others could actually reduce the likelihood. In addition, Gulati, Nohria, and Zaheer (2000) argue that network ties are important sources of referrals that enable prospective partners to identify and learn about each other's capabilities and reduce the informational asymmetries that increase contracting costs. In order to test the hypothesis, the authors define tie strength by the frequency of interaction between partners and their level of resource 
commitment to the relationship. Further, Rowley, Behrens, and Krackhardt (2000) explore the conditions under which strong and weak ties are positively related to firm performance. Specifically, the authors argue that whether or not firms form their strategic alliances through strong or weak ties depends on how it is structurally embedded in the network. In essence, ties can act as a social control agent in terms of governing how alliance partners behave or cooperate in the marketplace.

A few recent studies provide useful challenges and an extension to the traditional relational-based view of interfirm networks. Rindfleisch and Moorman (2001) examine the acquisition and utilization of information in new product alliances from a strength-of-ties perspective. Drawing upon network theory (Granovetter, 1973, 1983), the authors suggest that horizontal alliances have a lower level of relational embeddedness and a higher level of knowledge redundancy than do vertical alliances. The results also question the key underlying assumptions of the strength-of-ties literature. For instance, strong ties are typically assumed to share both high levels of embeddedness and high levels of redundancy; however, the findings of Rindfleisch and Moorman (2001) indicate that this assumption does not hold for organizational contexts. In an organizational context, strong ties are more likely to act as "bridges" than weak ties. Additionally, Khanna and Rivkin (2006) extend interfirm ties beyond the strength-of-ties literature and define ties by their content. Based upon a survey in Chile, the findings suggest that the content of ties (e.g., family connections, common owners) play a role in determining the boundary of a business group. Mariotti (2011) investigated how firms gather and combine knowledge through strengthened bridging ties and high quality relationships. Most recently, Lee, Kroll and Walters (2011) developed a model of corporate governance stages and suggested that, in transitional economics, corporate governance is likely to shift from a bureaucratic control-based structure to a more relational governance structure.

Although few studies have provided challenges and extensions to the relational-based view, a large amount of research is grounded in network theory (Granovetter, 1973, 1983). However, we should also realize that network theory originally examined individuals within those networks and not organizations. We should further investigate the theoretical boundaries of organizational network research. In other words, we are not clear as to whether or not individual ties can be fully applied to organizational research. Additionally, we have to acknowledge that organizations do not build ties, people build ties. If this is true, how managers transfer their personal ties to the organization becomes an interesting research question which has yet to be studied in detail. Lastly, there is no clear definition of the qualities of interorganizational ties, and other qualities of ties besides tie strength (i.e., 
distance, symmetry, etc.) have not been fully examined as well.

\section{The Structural Perspective and Research Gaps}

Despite the value and quality of work conducted under the relational perspective, many recent studies have moved from the relational perspective to a network structure perspective. For instance, Liao (2010) studies the firm's ability to process and create knowledge in interfirm networks from a structural perspective. Westbrock (2010) found that an efficient network typically has a dominant group in the structure of oligopolistic markets. The structural perspective is concerned with how the overall structure of networks and structural factors within networks affect and are affected by other factors such as member firms' strategic choices, performance, knowledge creation, and knowledge transfer. Overall, the structure of networks refers to vertical networks (e.g., vertical alliances or marketing channel networks that typically include suppliers, manufacturers, distributors, and/or retailers), horizontal networks (e.g., horizontal alliances and buying groups that are typically composed of competitors in the same industry and that share the same market), mixed networks that include both horizontal and vertical networks (e.g., multichannel networks), and intermarket or concentric networks (e.g., Japanese Keiretsu). Structural factors within networks refer to factors such as size, density, actors' positions (centrality), network composition, interlocking board memberships, and structural holes (e.g., Achrol \& Kotler, 1999; Fombrun, 1982; Gulati, Nohria, \& Zaheer, 2000; Provan \& Kenis, 2007; Sydow \& Windeler, 1998).

Early research in the structural perspective has attempted to understand and define interorganizational relations within marketing channels (Reve \& Stern, 1979), leaving little question as to why marketing has a long tradition of examining vertical relationships between firms. In the past, many authors conceive of networks in this sense (Snow et al., 1992). By definition, the vertical network is the organizational set of firms comprising vertical exchange relations (Achrol, 1997). Scholars have brought together a variety of research arenas relating to vertical networks such as interdependency, contracting, and relational behavior in marketing channels (e.g., Kumar, Heide, \& Wathne, 2011; Lusch \& Brown, 1996) and power (Walker, 1972). Achrol and Kotler (1999) argue that marketing can be a network integrator in vertical channels because the network members are highly specialized and the burden rests on marketing managers to organize information and resource flow.

In marketing, Ganesan et al. (2009) further brought vertical network research into a retailing context, finding that retailers are looking beyond their or- 
ganizational boundaries to develop and leverage the resources and capabilities of their supply chain partners to create superior value and competitive advantage in the marketplace. The authors also discuss how global sourcing, multichannel routes, and relationship-based innovation lead to performance improvements with regard to brand image, reputation, sales, profits, innovation, and relationships. Additionally, a recent study conducted by Zaheer and Bell (2005) concludes that firms with superior network structure may be better able to exploit their internal capabilities and thus enhance performance.

Horizontal networks have also been examined in recent literature (e.g., Frels, Shervani, \& Sriastava, 2003; Provan \& Sebastian, 1998; Rindfleisch \& Moorman, 2009; Rowley, Behrens, \& Krackhardt, 2000; Swaminathan \& Moorman, 2009; Zaheer \& Bell, 2005). For instance, Nygaard and Dahlstrom (2002) state that horizontal arrangements are increasingly deployed in organizational networks. In order to address the lack of horizontal alliances in the marketing literature, the authors examine the distribution system of two oil companies that operate through a horizontal alliance at the retail level in order to address the role of stress in horizontal alliances, the influence of role stress on organizational outcomes, and the organizational and communicative processes that influence the level of stress in alliances. Additionally, Rindfliesch and Moorman (2001) suggest that horizontal alliances have lower levels of relational embeddedness and higher levels of knowledge redundancy than vertical alliances.

Aside from vertical and horizontal networks, the concentric network is also a network form that marketers are becoming more and more aware of. The concentric network, also known as an intermarket network, is defined as an enterprise group consisting of affiliations that operate in several related and unrelated industries and center around a major corporation (Achrol \& Kotler, 1999) The concentric network, at this point, is largely a phenomenon of the Japanese and Korean business environment (Achrol, 1997). Normally, the enterprise group is organized around one or more major financial institutions in the financial market. However, we believe that concentric networks not only exist in the Japanese and Korean environments but also in the Western marketplace. A possible example is in Uzzi's (1997) study of structural embeddedness. Uzzi did not identify his research context as a concentric network. However, his study involves a major manufacturer surrounded by an interfirm network (e.g., design studio, warehouse, showroom, and retailer), which can be considered a concentric network.

Mixed networks, a fourth network structure, have rarely been examined, much less defined, in past literature. McGuire and Dow (2009) reviewed the major 
theoretical and empirical work of Japanese Keiretsu, dividing the keiretsu structure into vertical and horizontal networks and claiming that the distinction between the two is often blurred. Often, there is an overlap between the two. For instance, the overlap between the Mitsubishi horizontal and production centered grouping and the overlap between Toyota (vertical) and Mitsui (horizontal) groups are classic examples.

It seems that researchers have made considerable efforts to study vertical or horizontal networks. However, we take note that any discussion of vertical or horizontal network structures is likely to be oversimplified. Networks are characterized by permeable and evolving ties. For instance, each of the ties could move from horizontal to vertical structures and vice versa. Practically, simply examining horizontal networks may neglect the other vertical relationships the firms may have established that have an impact on the horizontal networks at play. Possibly, the combination of ties leads to superior performance instead of any one single vertical or horizontal tie. In other words, simply looking at vertical or horizontal networks separately may lead to inaccurate research results. As such, we believe that investigating the mixed network could possibly provide a new research arena.

\section{The Evolutionary Perspective and Research Gaps}

An already large and still growing body of literature concerning organizational networks draws attention to the importance of network evolution. The evolutionist perspective focuses on how and why changes in networks affect and/or are affected by firms' strategic choices, industry events, and institutional factors (i.e., changing social norms, laws, or regulations) within a network. For example, how do the changing size, density, and positions of new or existing firms in a network, joint venture, and alliance formation impact the relationships within those networks? Additionally, research has focused on the stages of relationship development among existing and potential network members.

Specifically, the majority of the body of work concerning the evolutionist perspective focuses on network formation and network dissolution. In the view of network formation, organizations build ties based upon theories of social and socioeconomic exchange (Larson \& Starr, 1993), social capital (Walker, Kogut, \& Shan, 1997), and structure roles. For instance, Larson and Starr (1993) detail the three stages of network building, focusing on dyads and converting dyadic ties to socioeconomic exchanges while layering the exchanges with multiple exchange processes. During the three stages, organizations selectively use the network dyads 
to match their business decision making. Further, Gulati (1993) investigates how social structure affects interfirm alliance formation patterns through a longitudinal study in which he proposes that the social context emerging from prior alliances and consideration of strategic interdependence influences partnership decisions between firms. The social network then facilitates new alliances by providing information to firms about the capabilities and reliability of the potential partners. As such, organizations create ties to manage uncertain environments and to satisfy their resource needs (Gulati \& Gargiulo, 1999).

In addition, organizational scholars investigate network evolution from other social theories other than social exchange which, to some extent, overlap with the motivational perspective. However, evolutionists focus upon the stage and process of building networks. For instance, changes in political and economic power can affect channel structure and firms' decisions in terms of social network formation (Dahab, Gentry, \& Sohi, 1996). Resource dependence theorists have argued that the formation of interorganizational ties, such as strategic alliances, is a result of underlying resource dependence (Pfeffer \& Nowak, 1976). In addition, Madhavan, Koka, and Prescott (1998) draw upon the structural perspective to theorize about how and why interfirm networks change over time. They argue that interfirm networks evolve in response to key industry events. Scholars of corporate strategy have suggested that firms form or change alliances to improve their strategic position in the network and in the marketplace (Contractor \& Lorange, 1988; Kogut, 1988; Porter \& Fuller, 1986). Interestingly, Gulati and Garguilo (1999) argue that the new alliance modifies the existing network, prompting a dynamic between organizational action and network structure. Through testing the ideas over a nine-year period, the study shows a new alliance may increase with their interdependence and also with their prior mutual alliances, common third parties, and joint centrality in the alliance networks.

In recent years, scholars have begun to investigate network dissolution. Due to the complexity of collecting data, the research is mostly theoretical. Baker, Faulkner, and Fisher (1998) analyzed the dissolution of interorganizational ties between advertising agencies and their clients as a function of competition, power, and institutional forces. Specifically, they find that most exchange relationships between advertising agencies and their clients are exclusive, and most last for several years; but competition, power, and institutional forces support or undermine these relationships. Powerful advertising agencies use resources to increase stability, but their clients mobilize resources to increase or decrease stability. Competition has an effect on tie dissolution, and institutional forces, such as changing norms, destabilize 
relationships.

Although researchers have made significant strides in understanding how networks evolve through joining new networks, modifying existing networks, and natural evolution within current networks, they have left a few questions relatively unexplored. Some scholars, for example, assume that exchange relationships between two firms exist as a given and seek to explain how those relations are formalized (c.f. Pisano, 1989). This assumption that exchange relations may guide tie formation between firms may actually lead to false conclusions. Some scholars, despite an understanding that other reasons may guide tie formation, may not account for network formation and change. For instance, little research has been conducted that explains if marketing capabilities are a resource that firms do not rely upon when entering a new network. Interestingly enough, though resource factors have been specified in the past, the question remains whether or not these resources are tangible (e.g., financial or human resources) or intangible (e.g., accessibility to other networks, capabilities in managing partnerships).

Further, a large body of studies in this domain focuses upon the formation of alliances instead of the formation and change of networks. Although the formation of alliances can provide insights into network formation, it is hard to know how other business networks (e.g., buying groups or business associations) form through this conceptual perspective. As such, research on informal business groups could be a possible future research arena. Lastly, arguably, institutional forces, such as cultural norms, play an important role in network formation. Although a few scholars (c.f. Peng, 2003; Peng \& Zhou, 2005) investigate how firms use network-centered strategies and how networks evolve in a transitional economy, little work has been done to compare network evolution in different cultures or to analyze network evolution that involves firms from more than one culture.

\section{The Interactionist Perspective and Research Gaps}

Much network research draws attention to the importance of interaction among firms (e.g., Belle, Katsikeas, \& Robson, 2010). The interactionist perspective focuses on the types, conditions, and consequences of interaction among firms in networks. As such, informational exchange, knowledge transfer, organizational learning, contractual and informal exchange, and reciprocity are important transactions that concern the interactionists. This perspective can be traced back to the 1970s. In general, early research simply focused on exchange interactions between entities in a network, and scholars agreed that conditions such as power, exchange 
behavior, and environmental forces served as important factors influencing and facilitating interactions among firms. For instance, Bensen (1975) proposes that resource concentration, power network dependence, resource abundance, and environmental control mechanisms are dimensions for firms to build networks and make interactive strategic decisions. Cook (1977) borrowed an exchange model for analysis of interorganizational relations and defines interorganizational linkages as networks of exchange interaction. Organizational activities are viewed as networks of exchange network relations. In order to develop his exchange model, Cook proposes that building interorganizational relationships such as alliance formation are correlated with power and position in the network.

In addition to these early conceptual articles, Larson (1992) further conducted a field study through a sample of dyadic relationships established by high growth entrepreneurial firms and finds that a process model of network formation, which emphasizes reciprocity and mutual interdependence. Jones, Hesterly, and Borgatti (1997) further combine network theory and transaction cost economics to assert that the interaction among firms are based upon asset specificity, demand uncertainty, task complexity, and frequency. These conditions drive firms to use their social mechanisms for exchange interaction.

Although early research focuses on the exchange interaction aspect of networks, little has been done to investigate alliance constellations in recent years. Das and Teng (2002) were the first scholars to propose that social interaction should be applied to alliance constellations. Alliance constellations are strategic alliances formed by multiple partner firms. Popular constellation types include R\&D consortia, joint bidding, and code-sharing among airlines and other industries. In the process of exchange among firms, reciprocity plays an important function for subsequent transactions.

While the early work with an interactional perspective is dominated by exchange theorists, researchers have focused on learning aspects of interaction in the past two decades. Scholars generally agree that economic exchanges among firms may involve both more obvious and less obvious tangible and intangible resources (such as market information). For instance, Uzzi (1997) finds that information exchange is very proprietary in arm's length ties and that learning synergies can arise from sharing insights within a network (Morgan, 2004). In addition, Bell and Zaheer (2007) examine the geographic impact on knowledge flow among networked firms. They acknowledge that knowledge- which is closely linked to a firm's innovativeness - is accessed across interorganizational boundaries and geographic space via networks. Using a combination of primary and secondary data on mutual fund firms, 
they find that institutional level ties (ties formed by the industry trade association structure arising incidentally to the firms involved rather than purposefully by the firms or their executives) are valuable in knowledge transmission only when such ties are geographically proximate. Organizational ties fail to act as transmitters of knowledge transference regardless of the location while, on the other hand, individual ties are superior for knowledge flow.

In general, past research has focused on common themes, such as exchange behavior among firms and organizational learning. However, there is much left to be done in terms of the interactivity among firms. Peters, Gassenheimer, and Johnston (2009) call for a more explicit connection to the interactivity and network literature. The nature of interactions, as a dynamic phenomenon, has presented researchers with challenges that are both conceptual and empirical. For instance, although scholars focus upon interfirm interaction, we still lack an understanding of how individual ties serve as transmitters of knowledge flow among or within firms. We do not yet know much about how specific knowledge links to a specific tie or resource. We also do not know how different ties influence the levels or amount of knowledge or information flow. In addition, we may need to seek a better understanding of how the types of interaction (e.g., frequency, the length of the relationship, etc.) impact organizational learning.

\section{The Governance Perspective and Research Gaps}

In recent years, scholars have recognized that the forms of governance may serve as key factors affecting research results. The governance perspective focuses on the locus of control within networks. Major examples of governance include network administrative organizations (NAO) networks that govern by an overarching entity that is separate from the firms within the network (i.e., a trade association), lead organizational governed networks (LOG) that are governed by a lead or dominant organization within the network, and participant governed networks (PGN) that are jointly governed by the many firms in the network.

Provan and Kenis (2007) propose that the simplest and most common form of network governance is the PGN, which is governed by the network members themselves with no separation of the governance entity. In health and human services, shared governance networks are common, in part because networks are often considered to be an important way of building community (Chaskin et al., 2001). In such a context, network members will only be likely to be committed to the goals of the network if they all participate on an equal basis. In business, shared governance 
may be used in small, multi-firm strategic alliances and partnerships to develop new products or attract new businesses, which could not be easily done through the independent efforts of network members (Venkatraman \& Lee, 2004). Shared governance may also be used in multilateral relations among banking firms to assemble financial investment (Eccles \& Crane, 1988).

At another extreme, LOG governance can occur in horizontal networks, most often when one organization has sufficient resources to play a lead role (Provan $\&$ Kenis, 2007). It can also occur in vertical, buyer-supplier relationships, especially when there is a single, powerful buyer/supplier/funder and several weak and small suppliers or buyers. The most classic example can be found in the Japanese Keiretsu model (Gerlach, 1992) and other similar models of cooperative buyer-supplier models in the U.S. (Uzzi, 1999) and Europe (Inzerilli, 1990; Lazerson, 1995). Additionally, lead organizations play important roles across different industries. For instance, in the entertainment industry, the LOG may be a major firm's studio (Jones \& DeFillippi, 1996). The LOG can also occur in health and human services; in community health, it may be a hospital or health clinic (Weiner \& Alexander, 1998). Teisman and Klijn (2002) also argue that a government agency can act as a lead organization in networks. Graddy and Chen (2006) focus on the role of the lead organization in governing child welfare in Los Angeles.

A third form of network governance is the NAO in which the basic governance model is a separate administrative entity set up to govern the network. Although the network members still interact with one another, the NAO model is highly centralized (Provan \& Kennis, 2007). For example, Human and Provan (2000) describe two networks in the wood processing industry that are both guided by an NAO. All the firms were for-profit, but the NAOs were non-profit. However, the NAO can be for a for-profit organization as in the case of Nexial International, the global accounting network discussed by Koza and Lewin (1999). Other scholars (e.g., McEvily \& Zaheer, 2004; Provan, Isett, \& Milward, 2004) argue that the NAO can also be used as a mechanism to enhance network legitimacy, to deal with unique and complex network level problems and issues, and to reduce the complexity of shared governance. In recent years, scholars (e.g., Provan et al., 2004) find that a more formalized NAO typically have board structures that include all or a subset of network members. The board addresses strategic concerns, leaving operational decisions to the NAO. Organizations join or form networks for a variety of reasons, including the need to gain legitimacy, serve clients efficiently, gain resources, and solve operational problems; and due to the different needs of the network, governance may vary. 
In the past, although marketing scholars have made significant efforts to address the impact of networks, few of them clearly distinguish the type of network governance examined. Of the existing literature, only that within the health and human service sector has even attempted to distinguish the type of governance examined. Even so, a clear identification of governance within those studies in health and human services was far from universal. Most articles lack a specific explanation of the governance structure. As such, there is also a need to classify the network governance structure and discuss the basic characteristics of each form of governance. In marketing, we suspect that each form of governance may have a different impact on marketing variables (e.g., new product development, increasing market share). On the other hand, positive marketing outcomes may require different forms of network governance. Last, firms may interact or be embedded within several different types of network governance. From a micro-level, how firms manage their position in a specific or multiple network governance is unknown, providing fuel for additional research in the area.

\section{$\overline{\text { Discussion }}$}

Research scholars have conducted interfirm network research for a few decades. However, much research was built upon one paradigm/perspective and lacked a complete theoretical view. For instance, research built upon the relational perspective was only concerned about the strength or quality of ties and ignored the potential network effects of network structure or network density. Research on network governance, however, put little emphasis on personal relationships. In other words, there is a need to combine different perspectives in order to have a complete understanding of how networks play roles in terms of gaining and maintaining competitive advantages in different areas such as, facilitating knowledge transfer and innovation, seeking financial support, and reducing consumer uncertainty towards a brand.

In addition, research on each of the paradigms was incomplete and may need to be developed further. For instance, the network evolutionists may conduct more longitudinal studies to examine the change of the relationships over time. Relational researchers may investigate the quality or characteristics of personal relationships besides the tie strength. For instance, the ties may be built upon reciprocity, and others may be built upon shared objectives. Relational ties may also involve emotions. According to past research, emotions play important roles in strategic decision making (Flint \& Fleet, 2011; Holmes et al., 2011). As such, studying the emotion elements in tie building can be meaningful. 
Further, this review provides researchers opportunities to engage in empirical network research. As Khoka (2010) suggested, for example, many antecedents have been left out of network research. For instance, resource and financial requirements and organizational structure should be studied as antecedents for organizational network research. In addition, a more balanced view of network performance and network costs needs to be researched. Also, a study of comparing formal and informal networks can be valuable. For instance, Chinese guanxi, which is considered as an informal relationship, can be a valuable resource to form formal relationships, perhaps because in high context cultures like China, networks are essential in business strategies (Liu, Atinc, \& Kroll, 2011).

Much network research has been done on a theoretical level, which perhaps is due to the difficulties of data collection. Though network structuralists, for example, may believe it is feasible to design simulations to calculate network intensity/density or distance between the nodes, it can be out of reach for managers to envision the structure of the network they embedded within. That is to say, there is a deep gap between theoretical network research and its practical value. This may explain why conceptual work tends to focus upon the network level of analysis, but empirical research on networks tends to examine alliances at the firm or relational level (See Table 1 and Table 2).

The conceptual perspectives have implications for managers representing organizations that are contemplating interfirm relationships, managing interfirm relationships, and/or considering expanding or exiting interfirm relationships. Thus, for managers, it is also important to understand different network perspectives, such as relational and structure perspectives. This is because network structure/density and other network characteristics in which the relationship is embedded may have effects on the quality of personal ties and such an impact may, as a result, influence the outcome of the relationships, such as sharing information or knowledge.

Firms also need to evaluate and balance resources, e.g, financial costs, knowledge, social capital/social ties before entering into a network. Additionally, the capability of managing interpersonal ties may determine the firm's potential capability of entering and maintaining its interfirm networks. Managers should also give attention to the structure of the network that the firm adopts because the structure may have potential impact on the amount of benefit the firm may obtain from its networks.

Moreover, as networks change, the benefits that the firm may gain from such a network may decline/increase. As other firms enter or withdraw from the network, managers need to design flexible strategies to react such a change. As a 
result, managers should be aware of both positive (e.g., share resources) and negative consequences (e.g., being dominated by another organization) of a network. Last, managers may need to be aware that network structure is culturally-based. For instance, the participant governed networks (PNG) may not apply to cultures which are rather hierarchical, e.g., India.

Thus, managers can be cognizant that there are multiple motivations for engaging in interfirm networks and be informed about the possible relational and structural composition of networks. Furthermore, there are consequences of the interactions between and/or among network firms and that there will be effects of network change over time (evolutionary). Finally, managers can note that there are several ways in which networks are controlled or governed.

This paper reviewed the research regarding interfirm networks, and as such, the purpose of this paper has been to provide an overview of the existing research into the phenomenon as well as directions for future research. As with any such review, there are limitations due to the conceptual nature of the paper. Unlike a metaanalysis, this paper does not provide a systematic statistical analysis of the interfirm network research findings. Also, we approached this review from a managerial marketing perspective as opposed to an economic perspective.

In this review, we have outlined the conceptual perspectives and methodological foundations of organizational networks. Organizations engaged in and/or considering developing an organizational network need to be aware of the various conceptual perspectives of interfirm networks so that the relationship potential is maximized. A better understanding of organizational network perspectives may not only potentially enhance existing relationships, paving the way for their further development and expansion, but also foster new relationships. In today's increasingly complex marketplace, successful organizations may no longer be huge, vertically-integrated firms. In many cases, they may be lean, specialized organizations that are part of a network of firms. Arguably, these developments signal the need for added and conceptually richer investigations of interfirm networks. Intuitively, there are varying levels of synergy as a result of interfirm collaboration. A clear understanding of the way in which these relationships are facilitated may maximize this synergy.

\section{$\overline{\text { Note }}$}

1 The research gap for each perspective is identified at the end of each section. The overall discussion of research gaps is summarized in the end of the paper. 


\begin{tabular}{|c|c|c|c|c|}
\hline 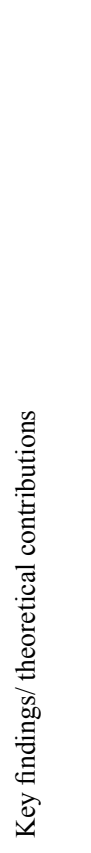 & 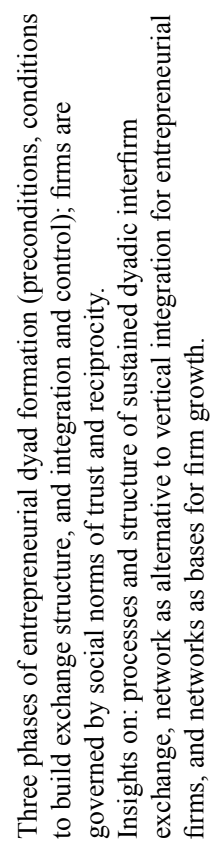 & 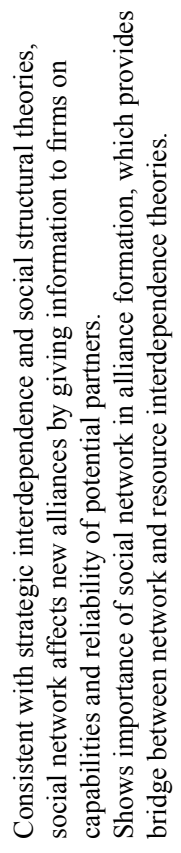 & 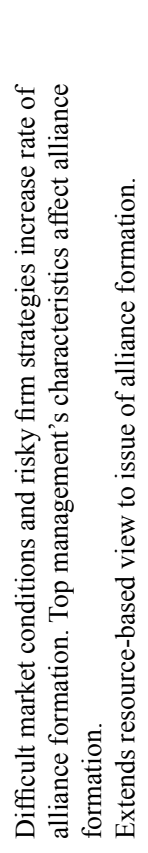 & 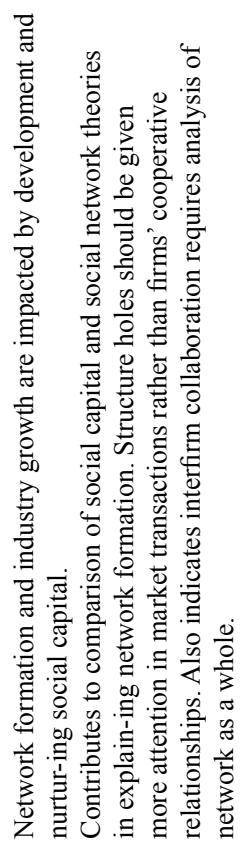 \\
\hline 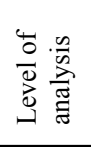 & 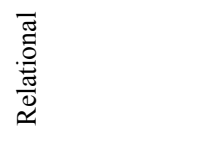 & 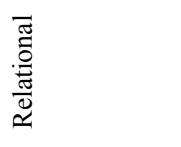 & 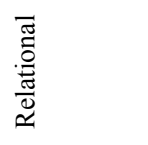 & 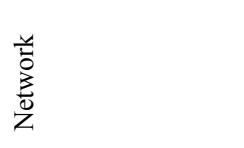 \\
\hline 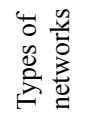 & 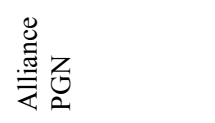 & 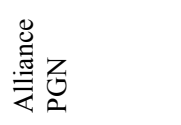 & 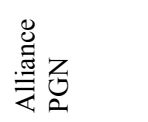 & $\begin{array}{l}\frac{\vec{J}}{\tilde{J}} \\
\dot{5}\end{array}$ \\
\hline 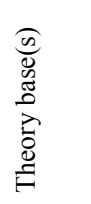 & 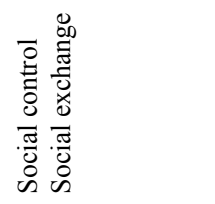 & 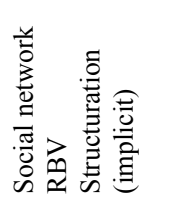 & $\vec{m}$ & 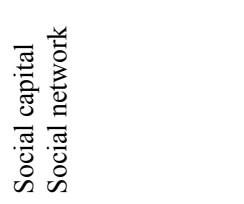 \\
\hline 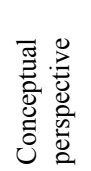 & 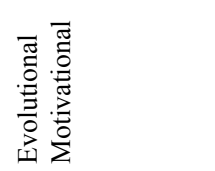 & 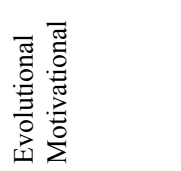 & 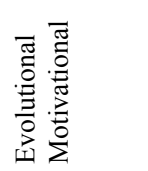 & 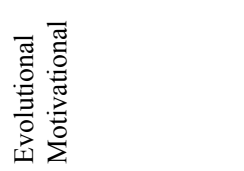 \\
\hline 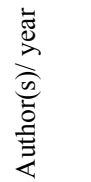 & 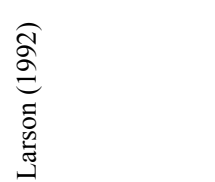 & 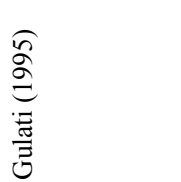 & 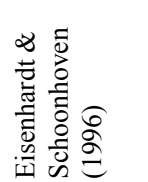 & 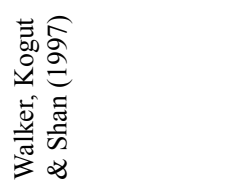 \\
\hline
\end{tabular}




\begin{tabular}{|c|c|c|c|c|}
\hline 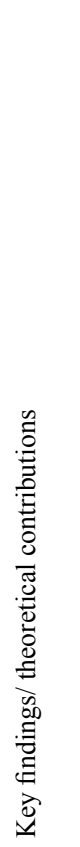 & 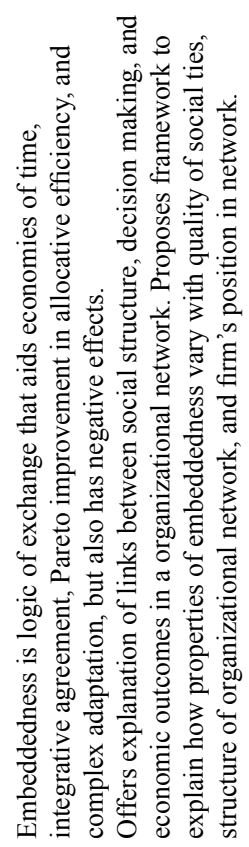 & 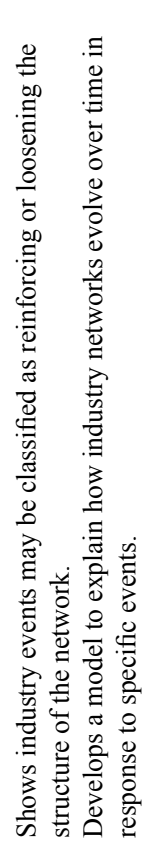 & 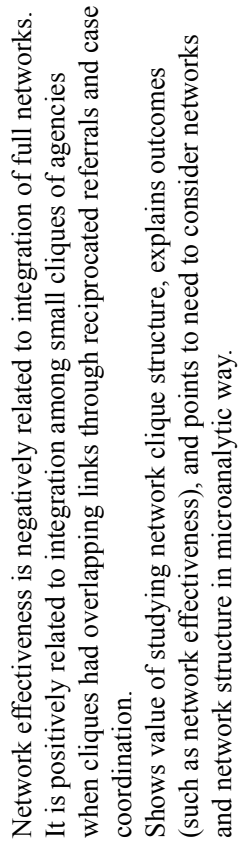 & 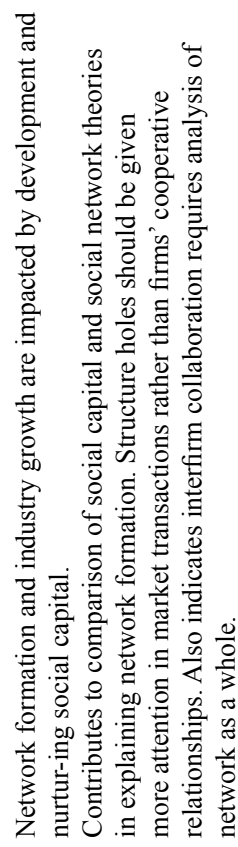 \\
\hline 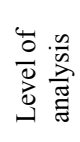 & $\begin{array}{l}\text { 咅 } \\
\text { zo } \\
\text { ż }\end{array}$ & 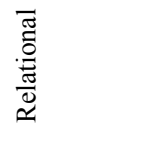 & 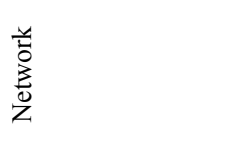 & 范 \\
\hline 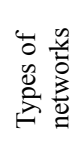 & ర్త & 莺 & Z & 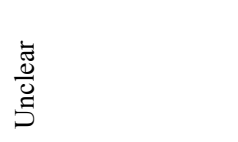 \\
\hline 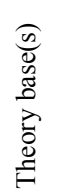 & 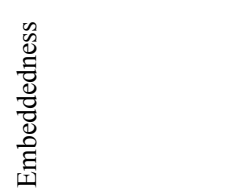 & 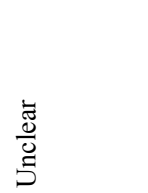 & 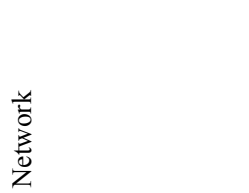 & 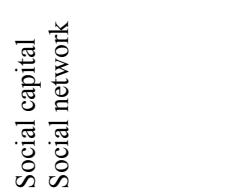 \\
\hline 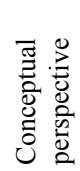 & 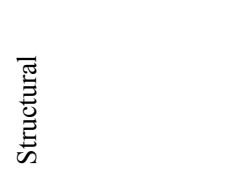 & 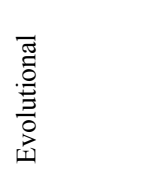 & 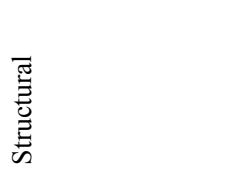 & 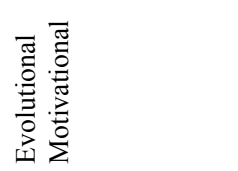 \\
\hline 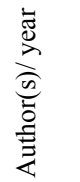 & 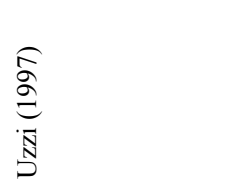 & 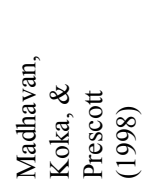 & 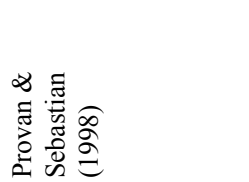 & 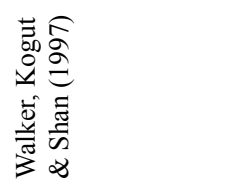 \\
\hline
\end{tabular}




\begin{tabular}{|c|c|c|c|c|}
\hline 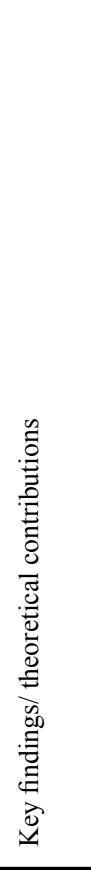 & 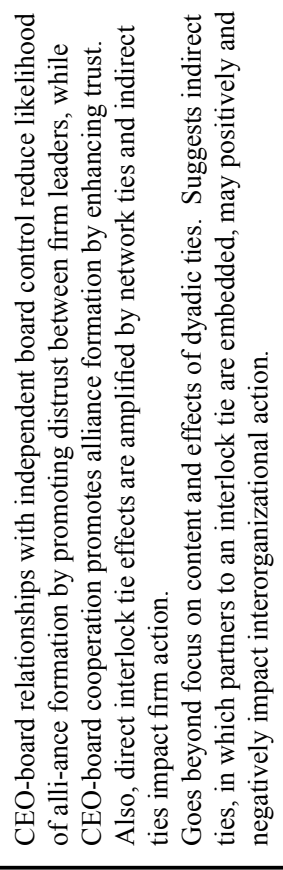 & 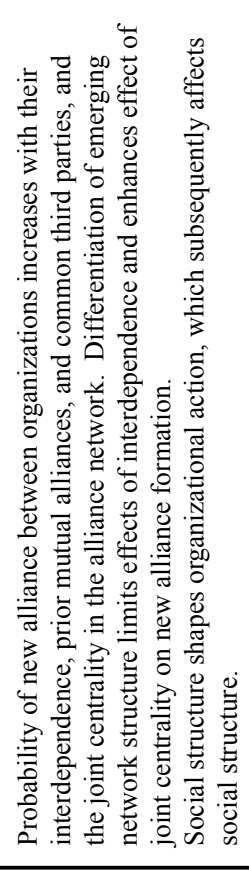 & 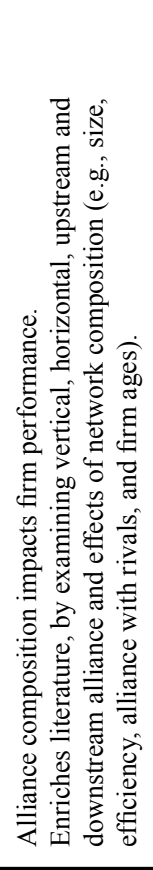 & 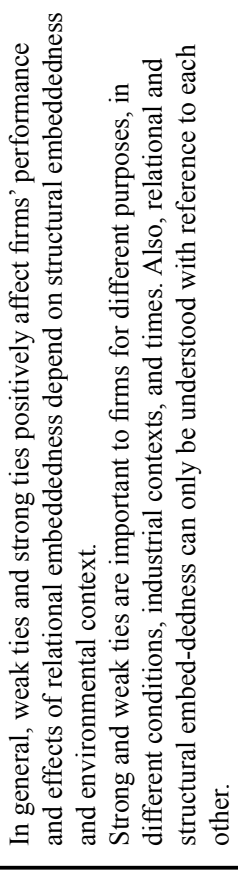 \\
\hline 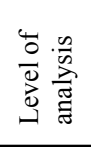 & 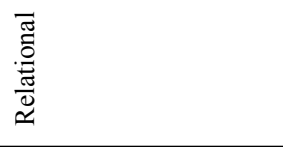 & 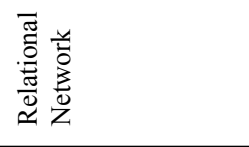 & 产 & 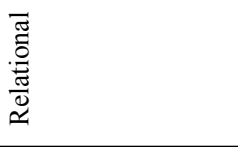 \\
\hline 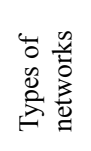 & 竞 & 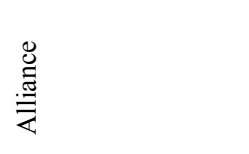 & 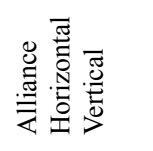 & 导 \\
\hline 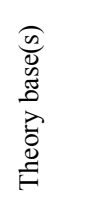 & 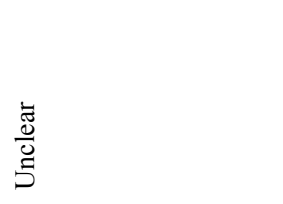 & 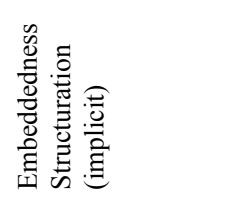 & $\begin{array}{l}\frac{\bar{\Xi}}{\tilde{J}} \\
\tilde{s}\end{array}$ & 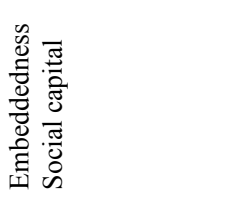 \\
\hline 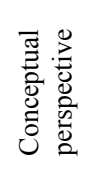 & 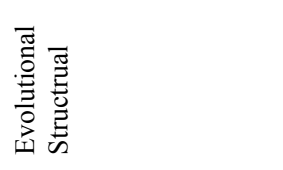 & 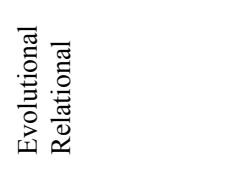 & 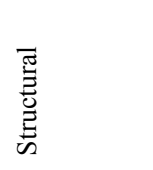 & 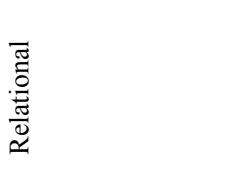 \\
\hline 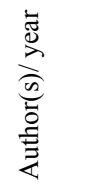 & 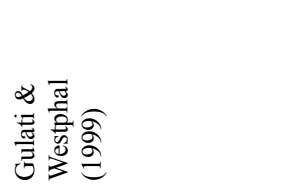 & 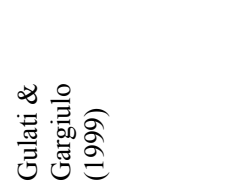 & 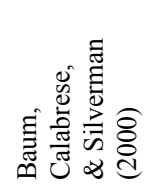 & 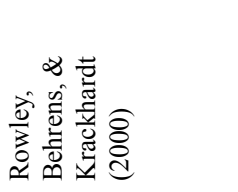 \\
\hline
\end{tabular}




\begin{tabular}{|c|c|c|c|}
\hline 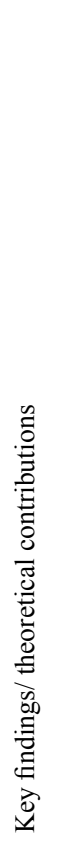 & 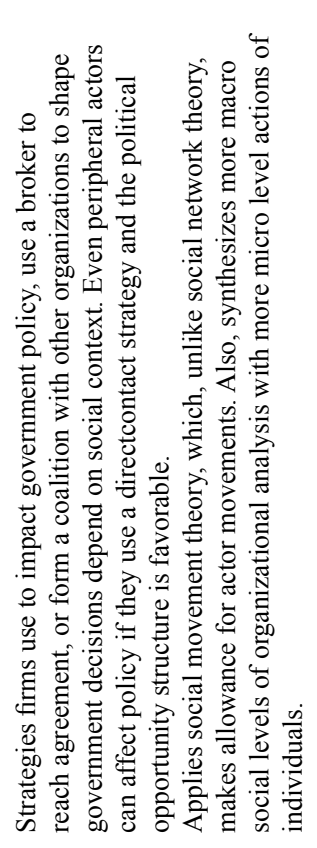 & 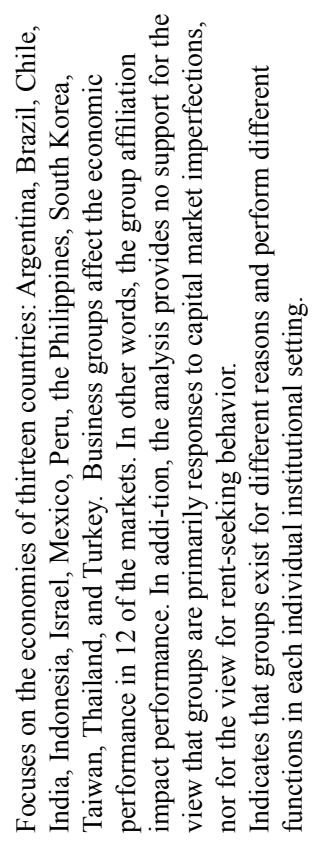 & 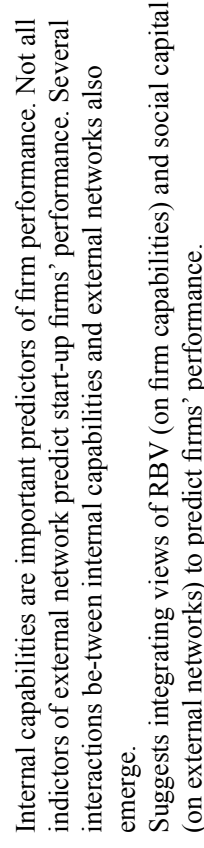 \\
\hline 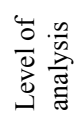 & 声 & $\begin{array}{l}\text { ü } \\
\text { ż } \\
\text { ż }\end{array}$ & 声 \\
\hline 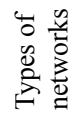 & $\begin{array}{l}\frac{\vec{\Xi}}{\tilde{J}} \\
\tilde{s}\end{array}$ & 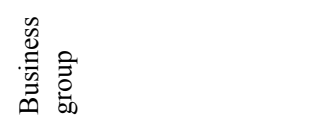 & $\begin{array}{l}\frac{\overrightarrow{\tilde{J}}}{\tilde{J}} \\
\underline{s}\end{array}$ \\
\hline 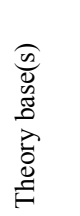 & 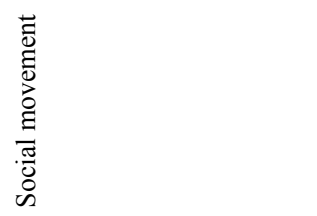 & 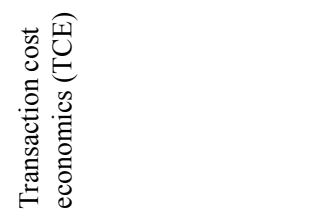 & 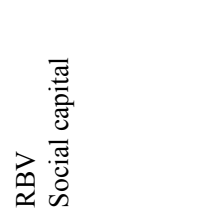 \\
\hline 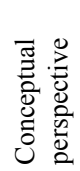 & 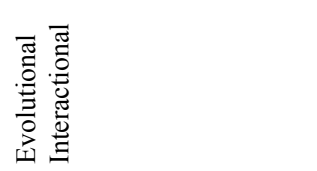 & 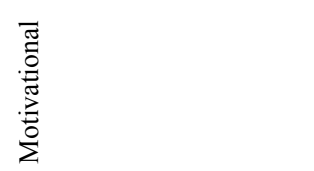 & 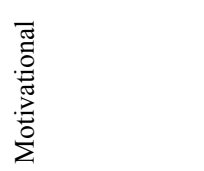 \\
\hline 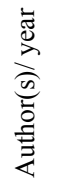 & 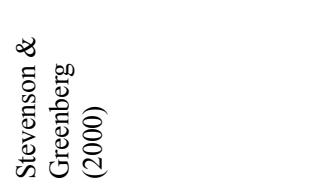 & 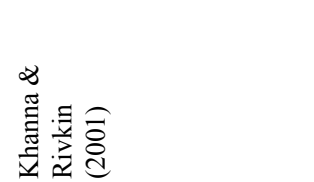 & 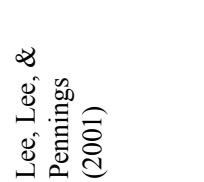 \\
\hline
\end{tabular}




\begin{tabular}{|c|c|c|c|c|}
\hline 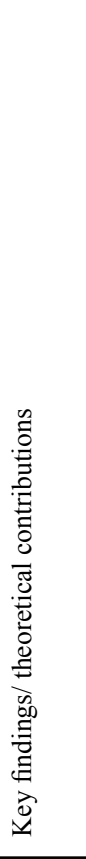 & 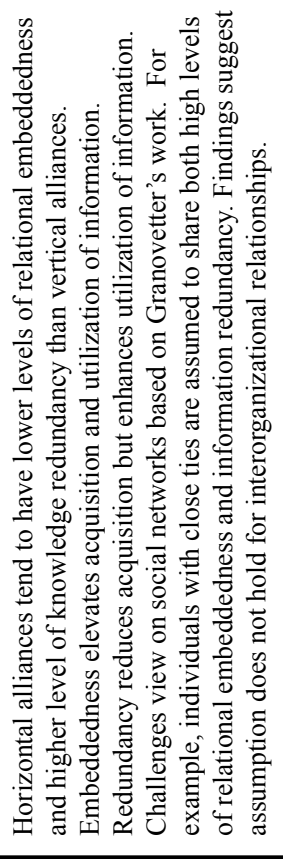 & 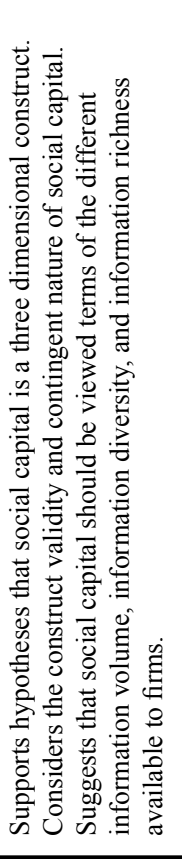 & 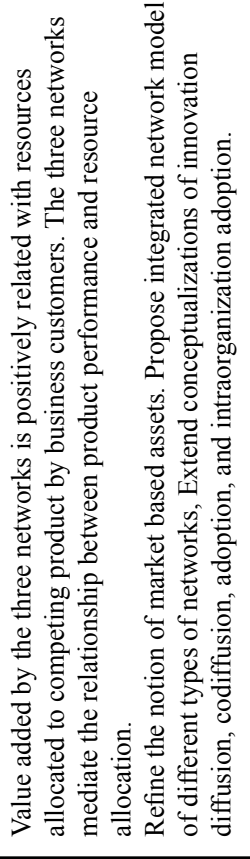 & 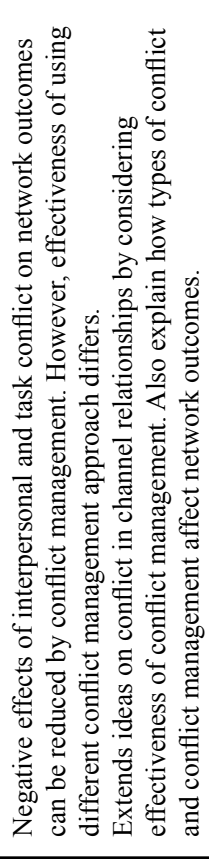 \\
\hline 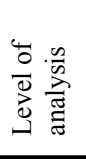 & 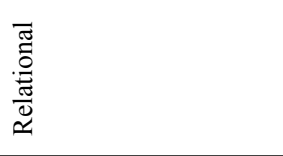 & 罣 & 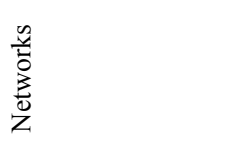 & 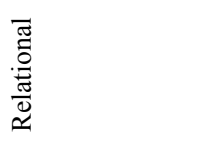 \\
\hline 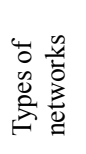 & 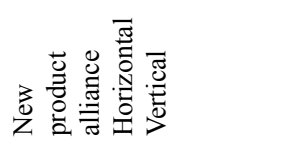 & 莺 & 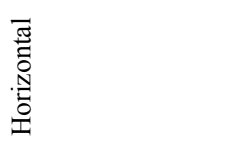 & $\begin{array}{l}\frac{\grave{\Xi}}{\mathscr{J}} \\
\vdots\end{array}$ \\
\hline 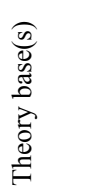 & 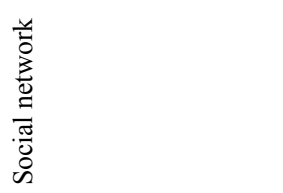 & 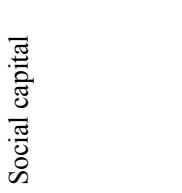 & $\begin{array}{l}\frac{\ddot{\Xi}}{0} \\
\dot{s}\end{array}$ & $\begin{array}{l}\frac{\tilde{\Xi}}{\tilde{\Xi}} \\
\dot{s}\end{array}$ \\
\hline 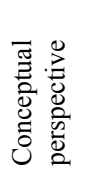 & 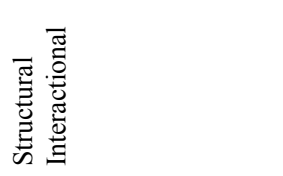 & . & 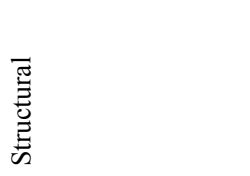 & 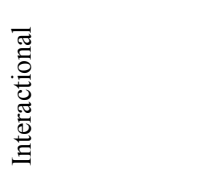 \\
\hline 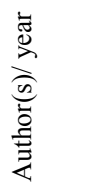 & 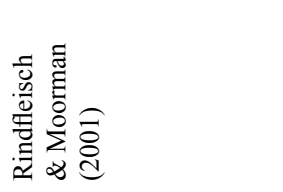 & 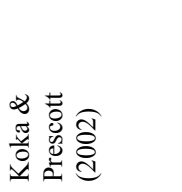 & 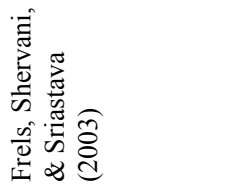 & 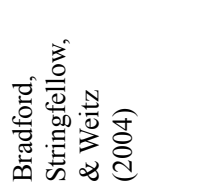 \\
\hline
\end{tabular}




\begin{tabular}{|c|c|c|c|}
\hline 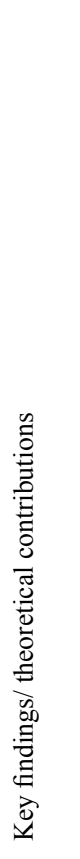 & 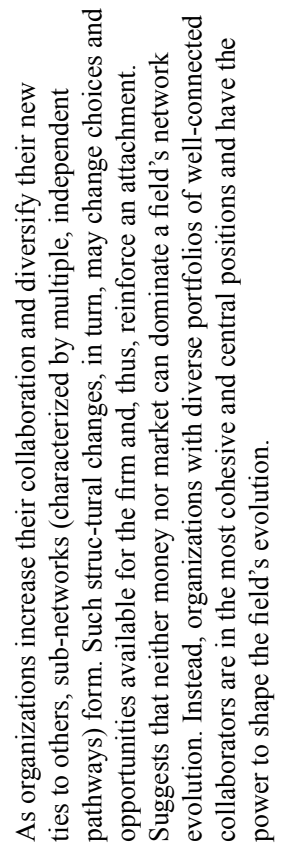 & 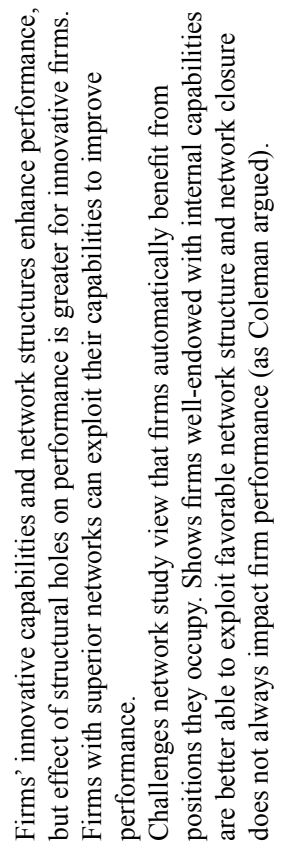 & 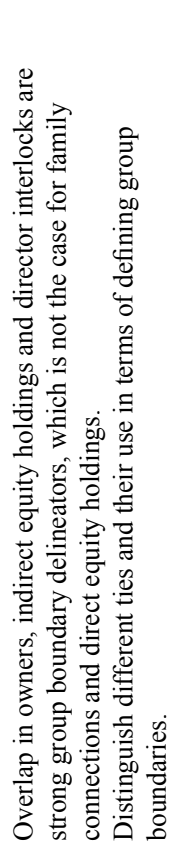 \\
\hline 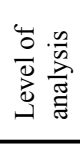 & 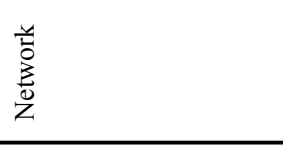 & 声 & 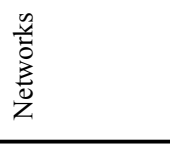 \\
\hline 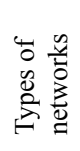 & 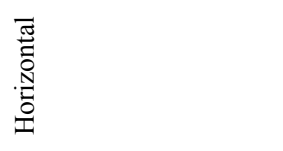 & Z & 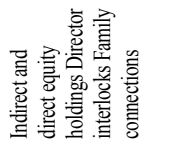 \\
\hline $\begin{array}{l}\text { त्ञ } \\
0 \\
0 \\
0 \\
0 \\
2 \\
0 \\
0 \\
0\end{array}$ & $\frac{\overrightarrow{\tilde{J}}}{\frac{\tilde{J}}{\tilde{g}}}$ & 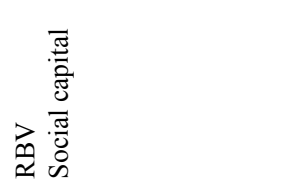 & 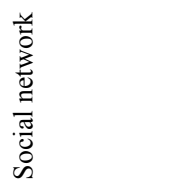 \\
\hline 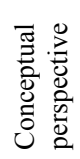 & 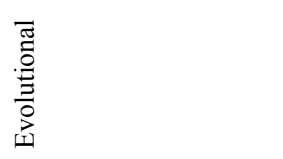 & 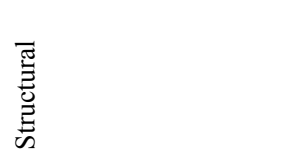 & 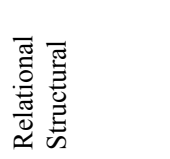 \\
\hline 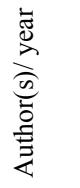 & 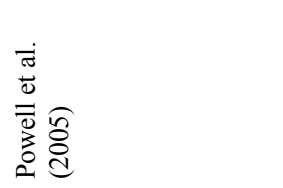 & 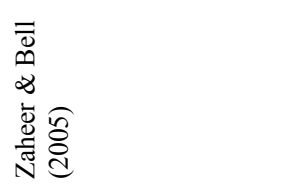 & 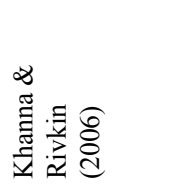 \\
\hline
\end{tabular}




\begin{tabular}{|c|c|c|c|}
\hline 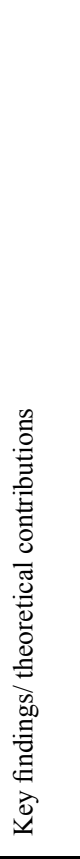 & 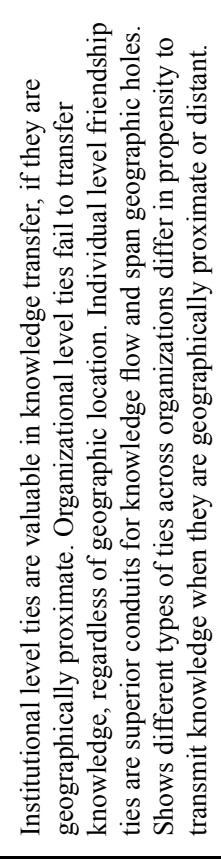 & 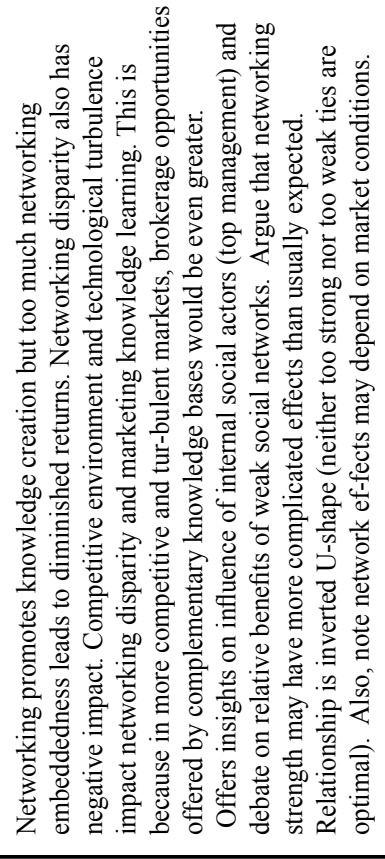 & 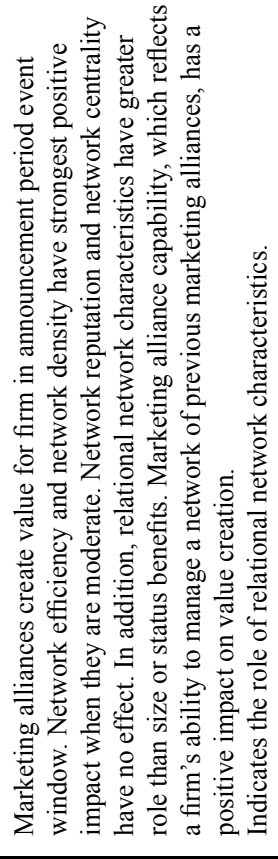 \\
\hline 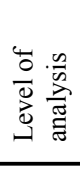 & 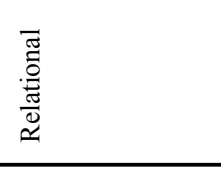 & 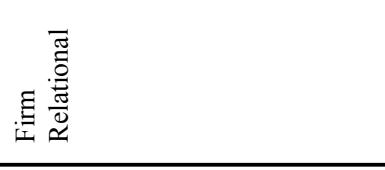 & $\begin{array}{l}y \\
\overline{0} \\
3 \\
0 \\
0\end{array}$ \\
\hline 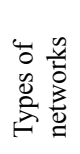 & 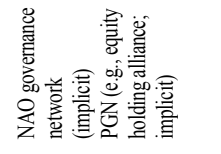 & $\begin{array}{l}\frac{\vec{E}}{\tilde{E}} \\
\tilde{s}\end{array}$ & 总 \\
\hline 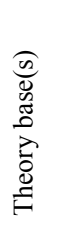 & 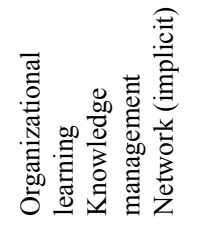 & 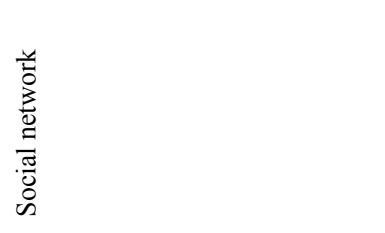 & 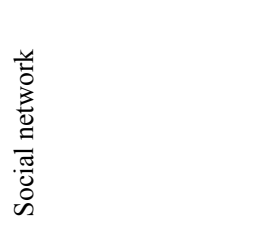 \\
\hline 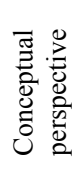 & 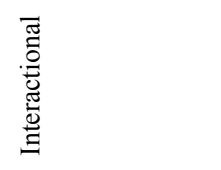 & 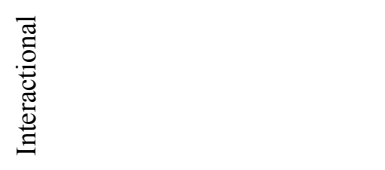 & 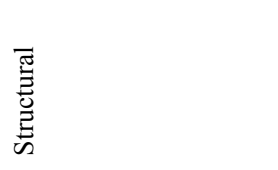 \\
\hline 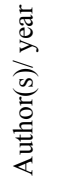 & 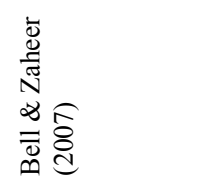 & 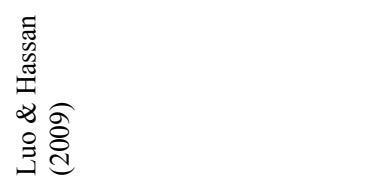 & 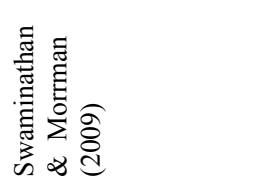 \\
\hline
\end{tabular}




\begin{tabular}{|c|c|c|}
\hline 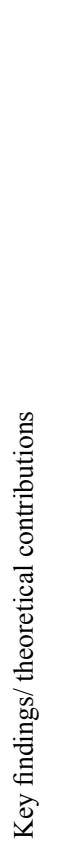 & 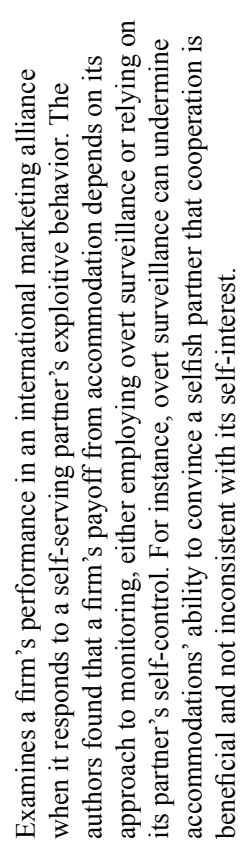 & 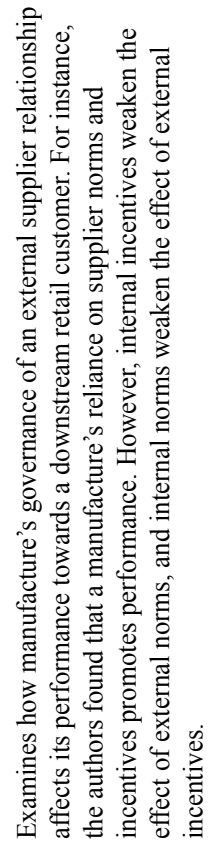 \\
\hline 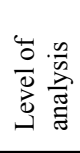 & 严 & 章 \\
\hline 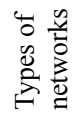 & 莺 & 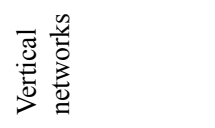 \\
\hline $\begin{array}{l}\text { (n) } \\
0 \\
0 \\
0 \\
0 \\
2 \\
0 \\
0 \\
0\end{array}$ & 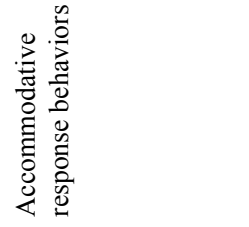 & $\frac{\overrightarrow{\tilde{J}}}{\frac{\vec{J}}{\tilde{s}}}$ \\
\hline 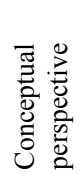 & 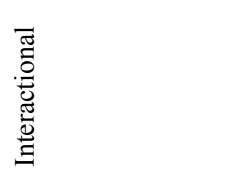 & 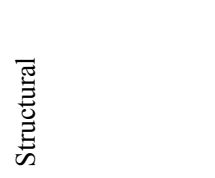 \\
\hline 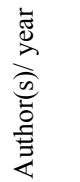 & 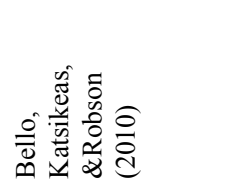 & 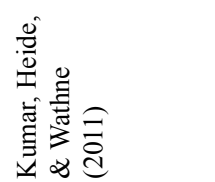 \\
\hline
\end{tabular}




\begin{tabular}{|c|c|c|c|}
\hline 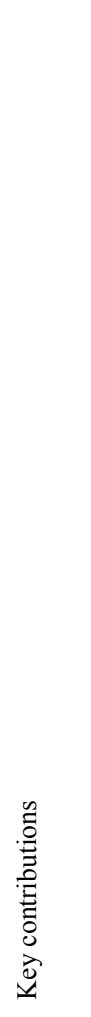 & 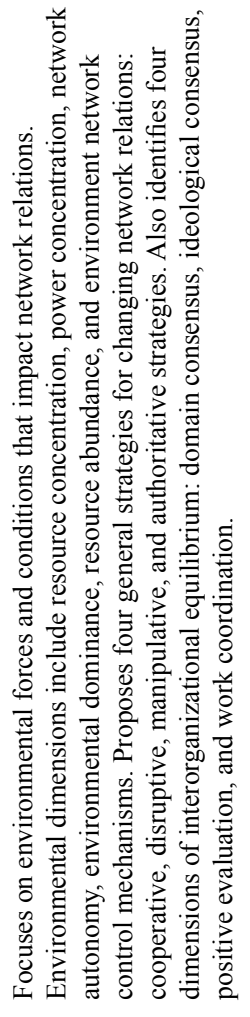 & 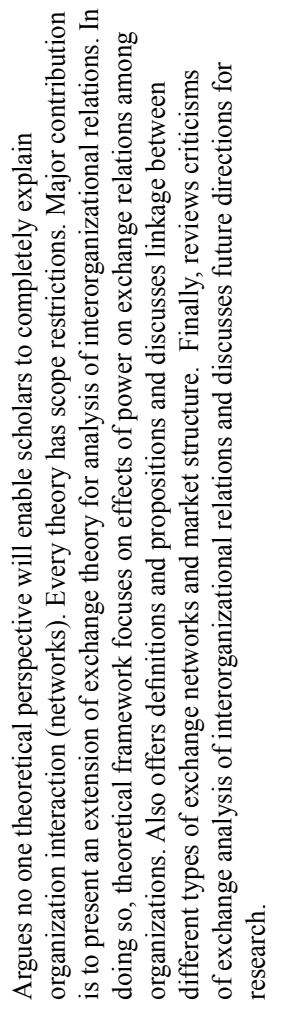 & 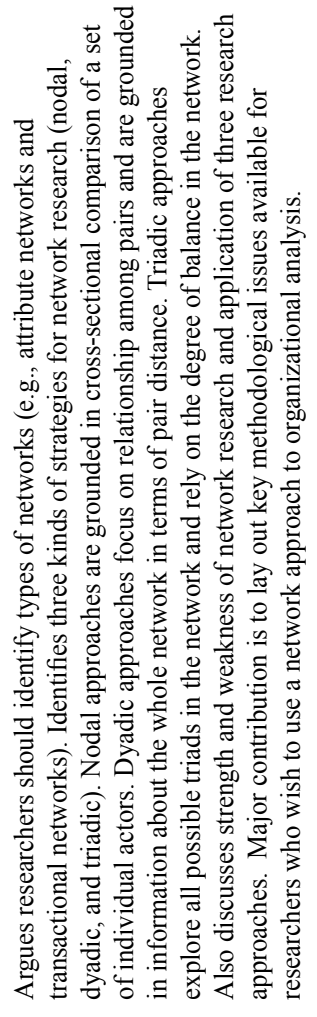 \\
\hline 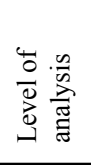 & 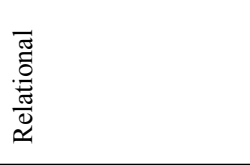 & 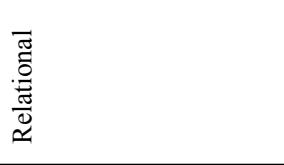 & 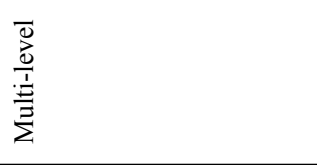 \\
\hline 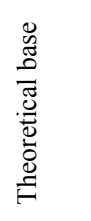 & 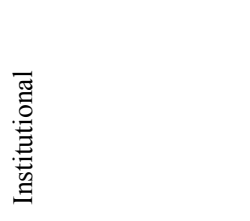 & 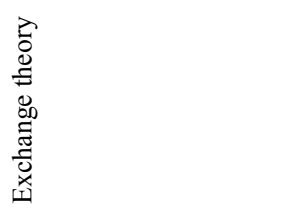 & $\begin{array}{l}\frac{\dot{\Xi}}{\tilde{J}} \\
\dot{g}\end{array}$ \\
\hline 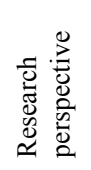 & 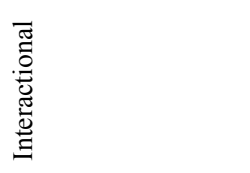 & 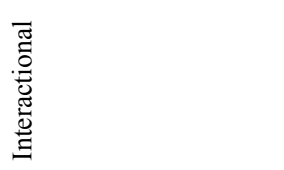 & 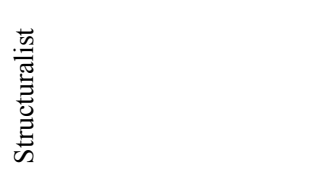 \\
\hline 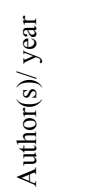 & 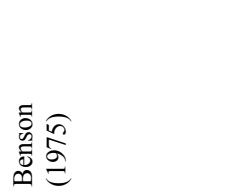 & 范尽 & 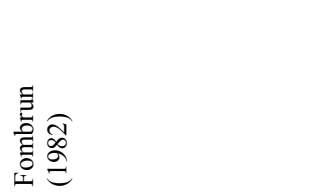 \\
\hline
\end{tabular}




\begin{tabular}{|c|c|c|c|c|}
\hline 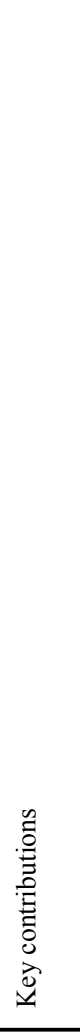 & 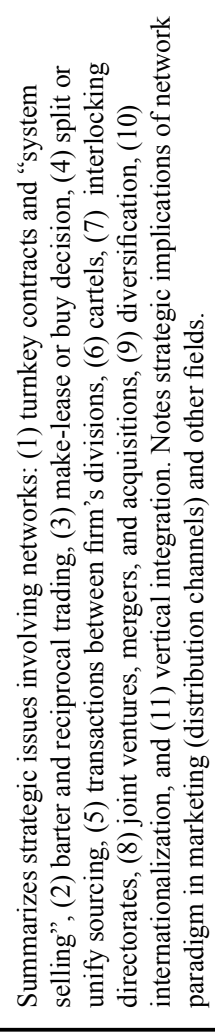 & 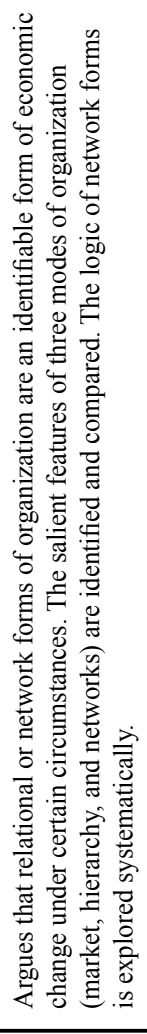 & 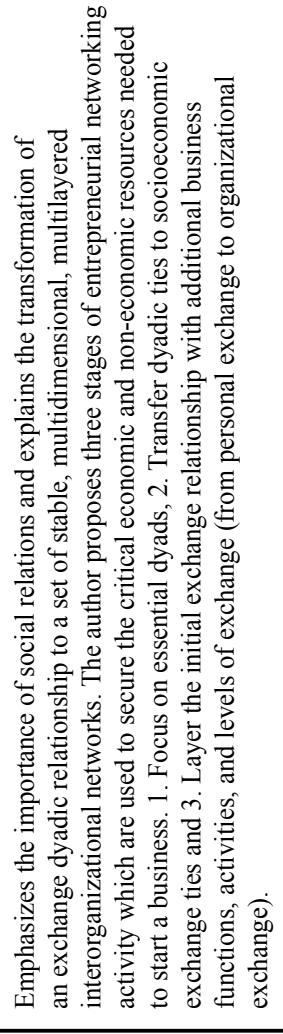 & 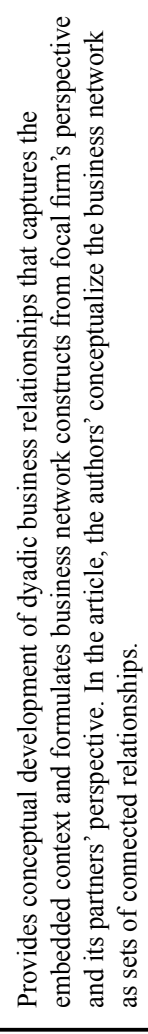 \\
\hline 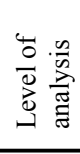 & 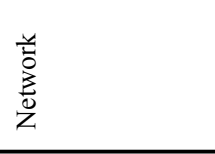 & 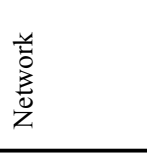 & 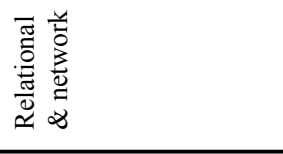 & 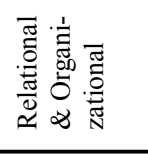 \\
\hline 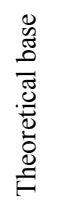 & 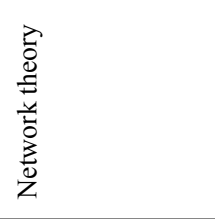 & 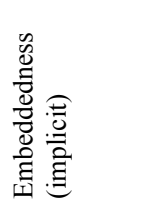 & 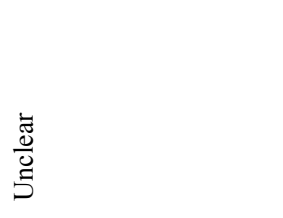 & 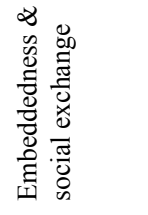 \\
\hline 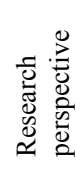 & 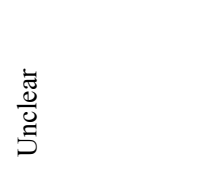 & 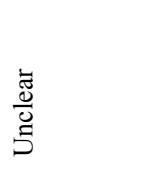 & $\begin{array}{l}\frac{\vec{\Xi}}{\tilde{J}} \\
\underline{5}\end{array}$ & 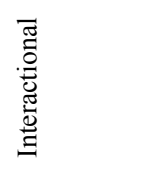 \\
\hline 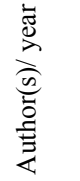 & 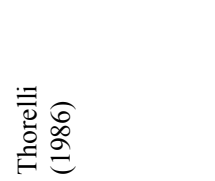 & 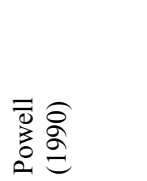 & 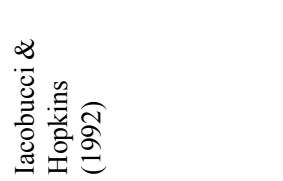 & 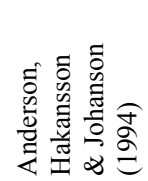 \\
\hline
\end{tabular}




\begin{tabular}{|c|c|c|c|c|c|}
\hline 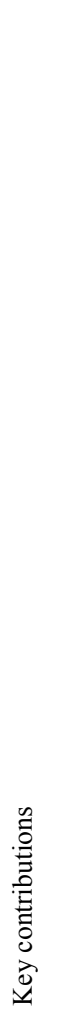 & 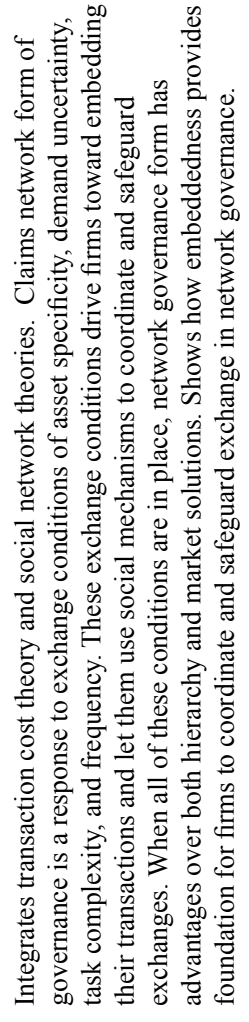 & 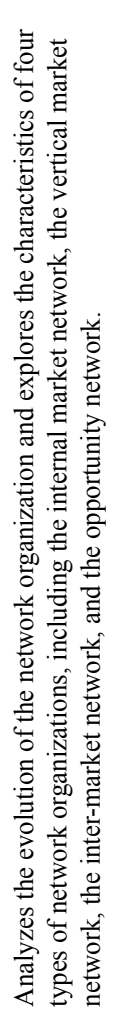 & 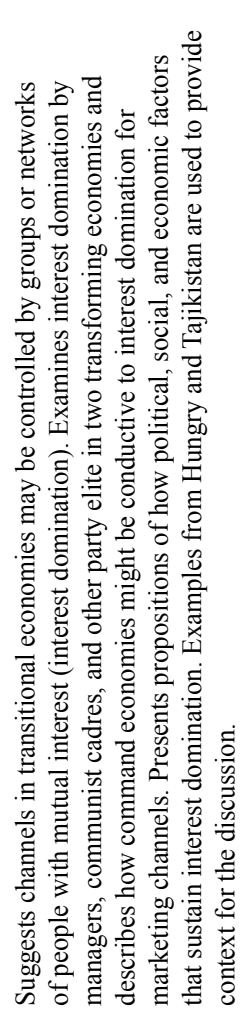 & 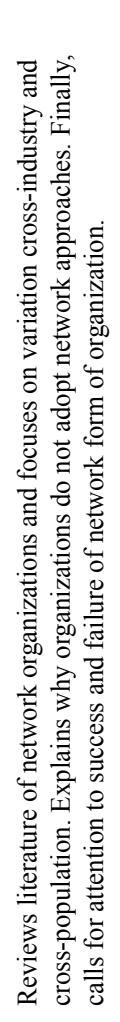 & 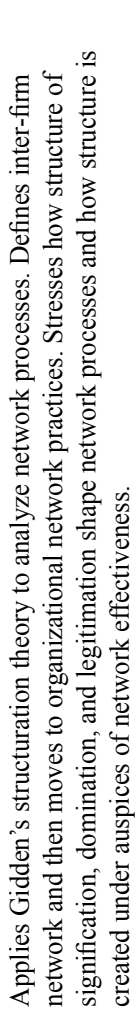 \\
\hline 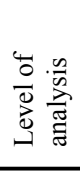 & 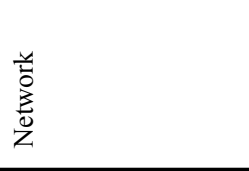 & 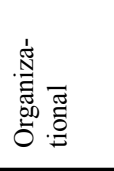 & 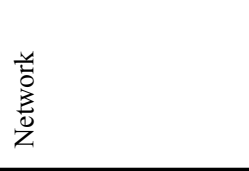 & 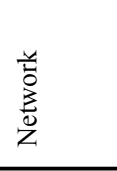 & 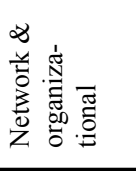 \\
\hline 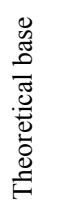 & 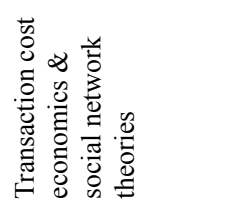 & $\begin{array}{l}\frac{\tilde{\Xi}}{\tilde{J}} \\
\stackrel{\Xi}{5}\end{array}$ & 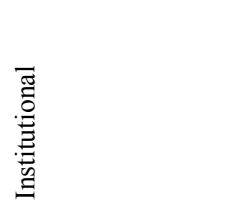 & $\begin{array}{l}\frac{\vec{\Xi}}{\tilde{J}} \\
\vec{J}\end{array}$ & 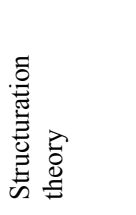 \\
\hline 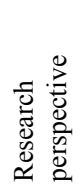 & 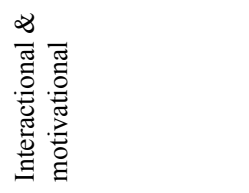 & 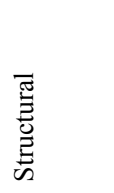 & 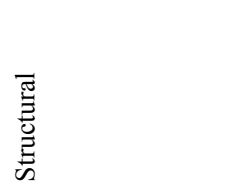 & 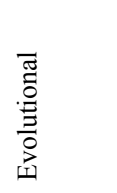 & 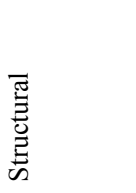 \\
\hline 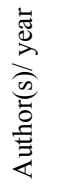 & 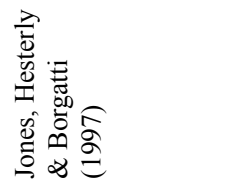 & 总令 & 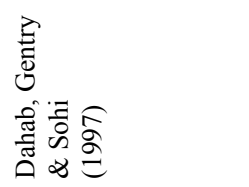 & 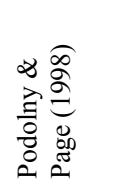 & 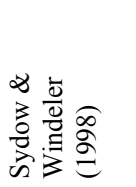 \\
\hline
\end{tabular}




\begin{tabular}{|c|c|c|c|c|}
\hline 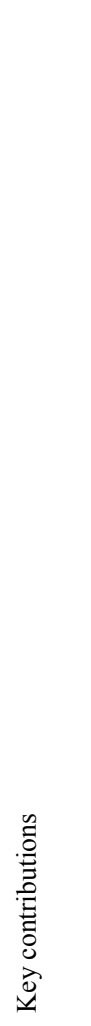 & 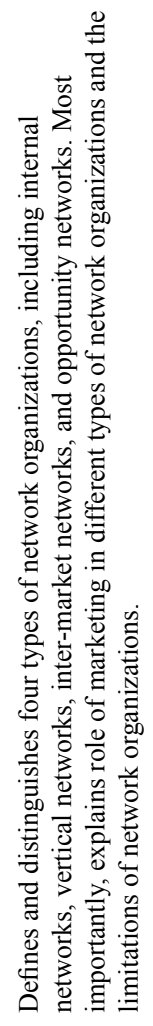 & 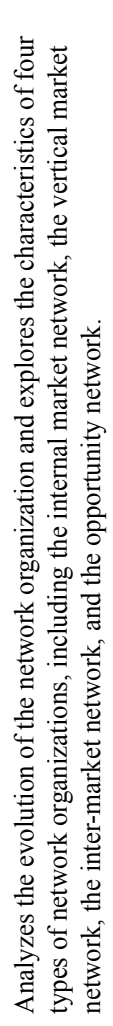 & 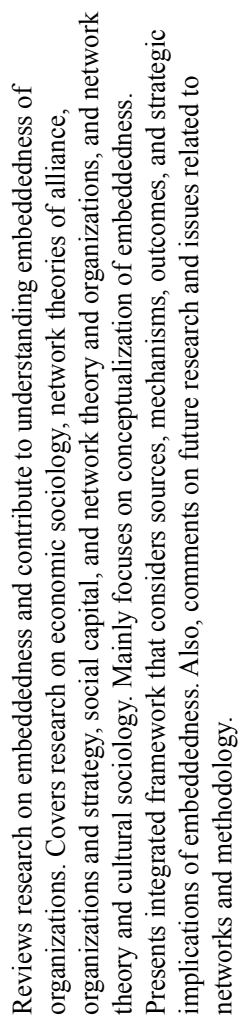 & 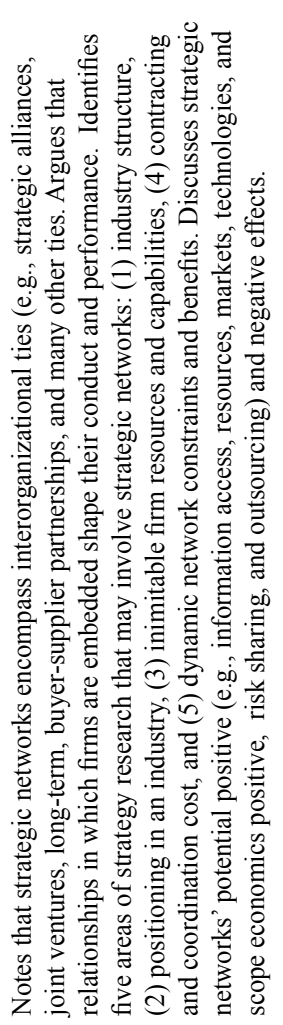 \\
\hline 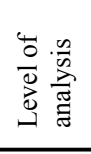 & 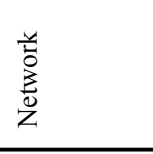 & 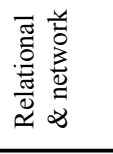 & 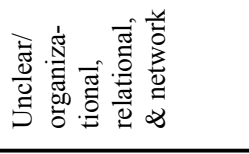 & 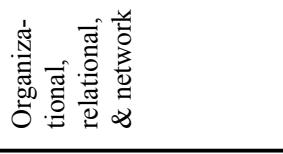 \\
\hline 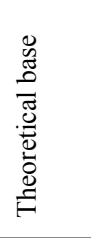 & 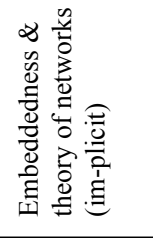 & 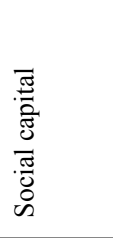 & 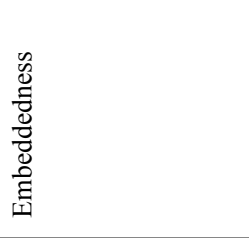 & 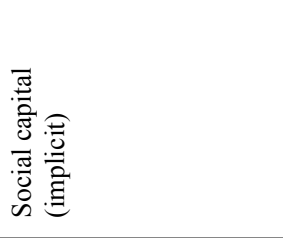 \\
\hline 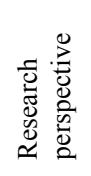 & $\begin{array}{l}\bar{J} \\
\text { 总 } \\
\text { 总 }\end{array}$ & 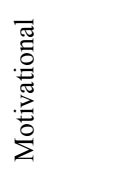 & 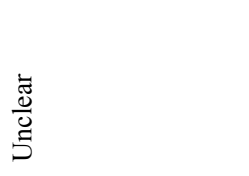 & 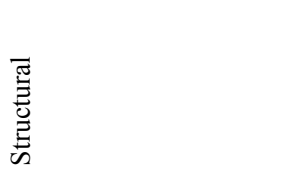 \\
\hline 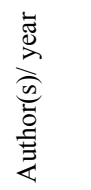 & 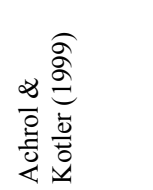 & $\Xi \Xi$ & 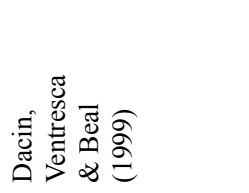 & 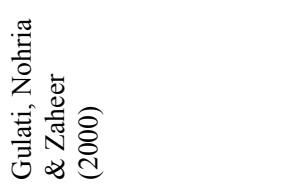 \\
\hline
\end{tabular}




\begin{tabular}{|c|c|c|c|c|}
\hline 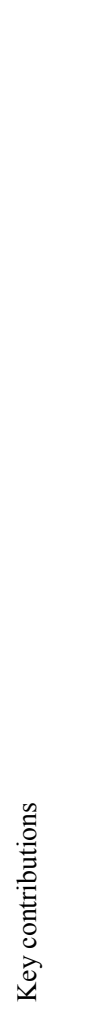 & 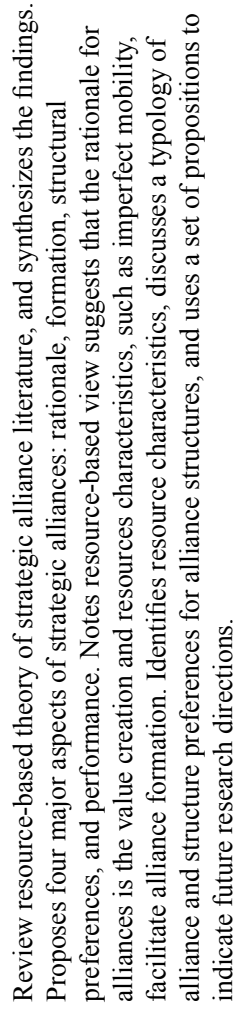 & 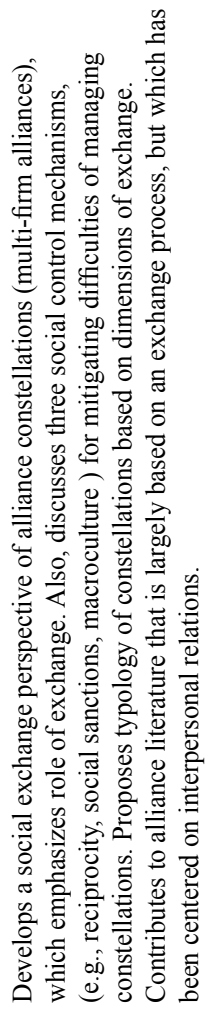 & 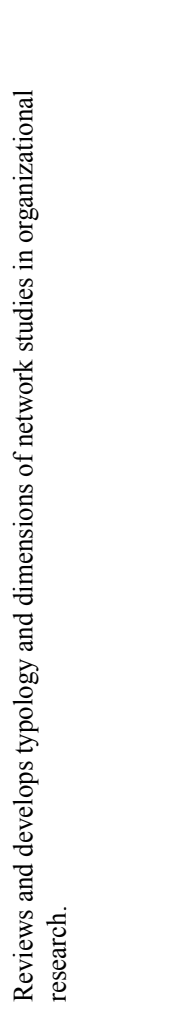 & 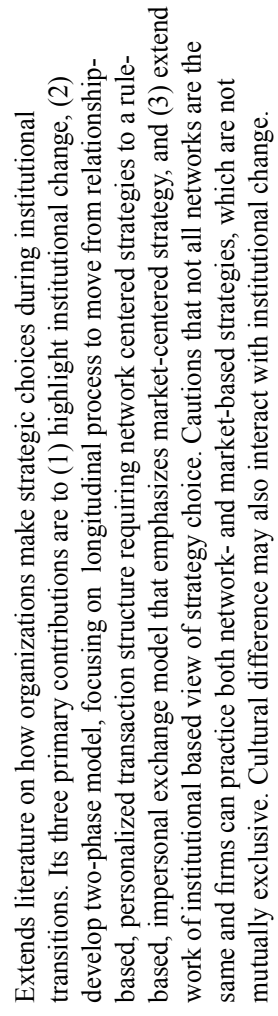 \\
\hline 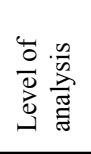 & 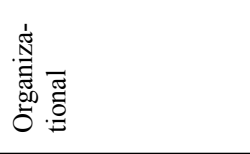 & 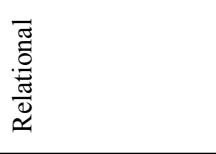 & 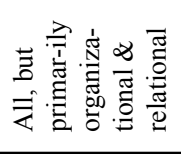 & 国 \\
\hline 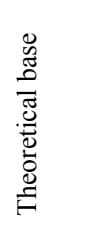 & 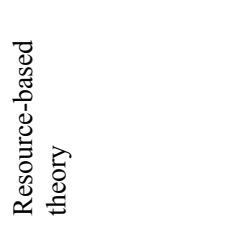 & 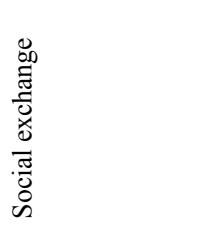 & 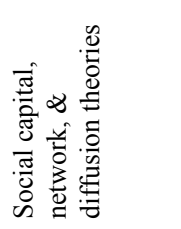 & 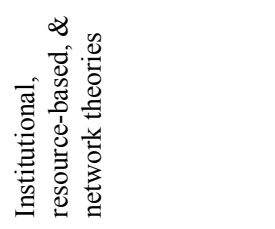 \\
\hline 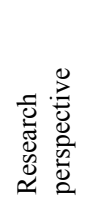 & 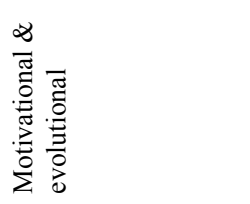 & 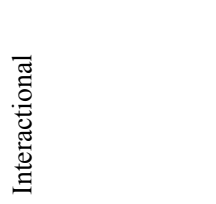 & $\frac{\frac{\vec{d}}{\tilde{J}}}{\dot{s}}$ & 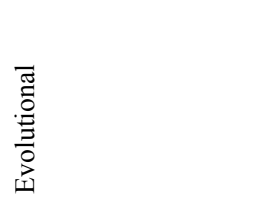 \\
\hline 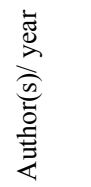 & 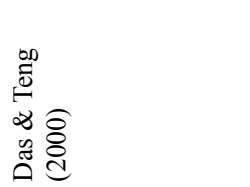 & 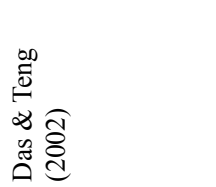 & 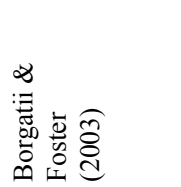 & 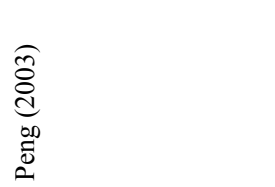 \\
\hline
\end{tabular}




\begin{tabular}{|c|c|c|c|}
\hline 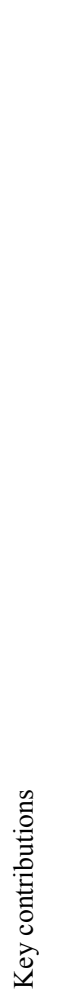 & 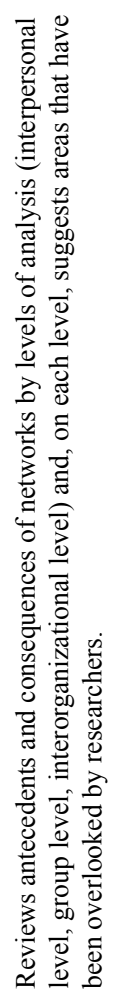 & 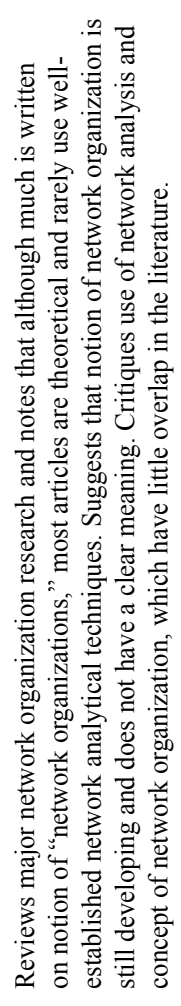 & 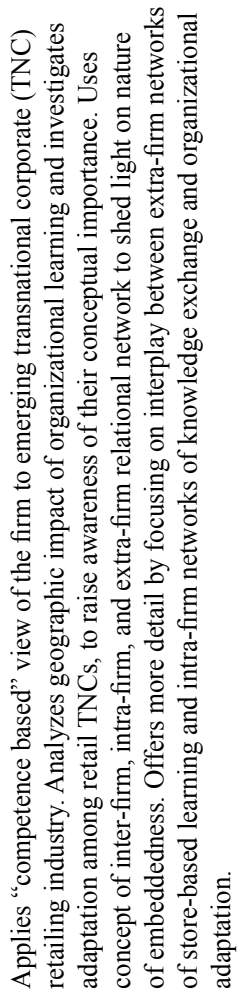 \\
\hline 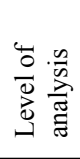 & \& & 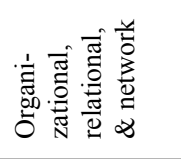 & 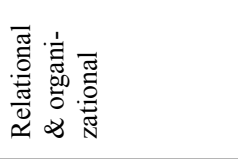 \\
\hline 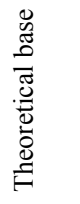 & $\frac{\overrightarrow{\tilde{d}}}{\frac{\tilde{d}}{\tilde{s}}}$ & $\frac{\ddot{\Xi}}{\tilde{\Xi}}$ & 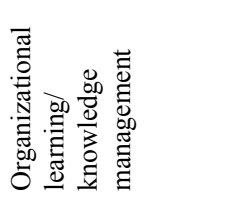 \\
\hline 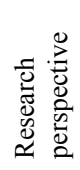 & $\begin{array}{l}\frac{\tilde{\Xi}}{\tilde{J}} \\
\underline{s}\end{array}$ & $\frac{\overrightarrow{\tilde{J}}}{\frac{\vec{d}}{\tilde{J}}}$ & 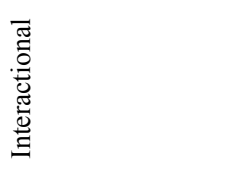 \\
\hline 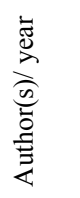 & 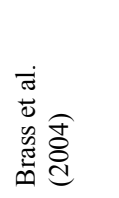 & 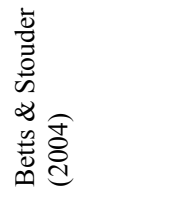 & 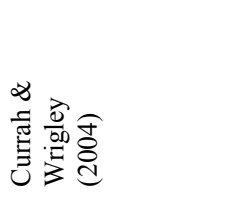 \\
\hline
\end{tabular}




\begin{tabular}{|c|c|c|c|c|}
\hline 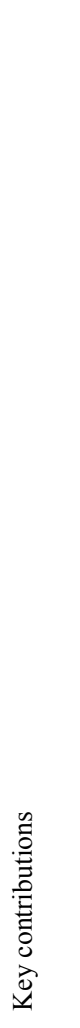 & 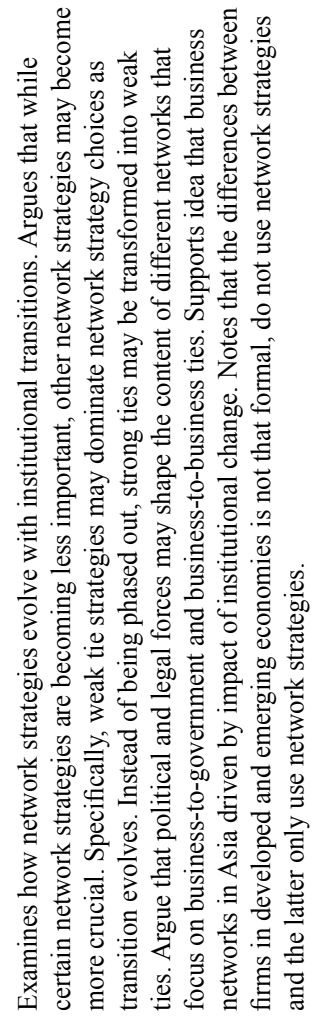 & 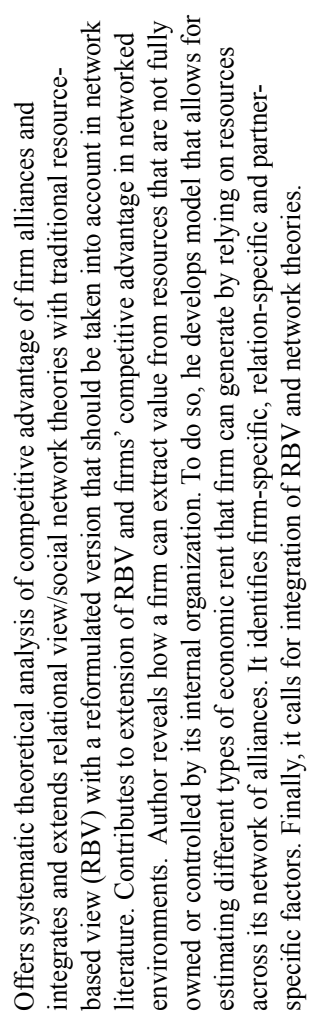 & 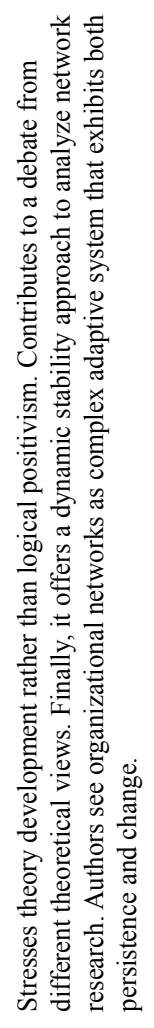 & 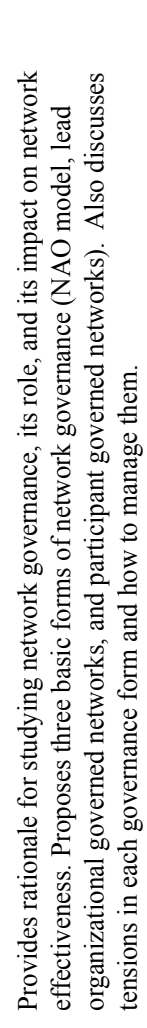 \\
\hline 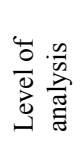 & 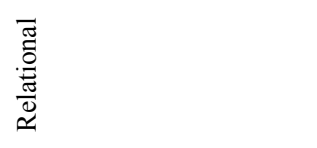 & 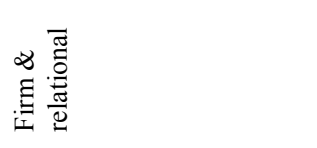 & 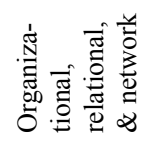 & 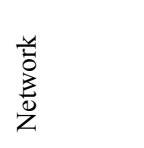 \\
\hline 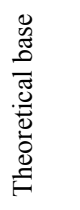 & 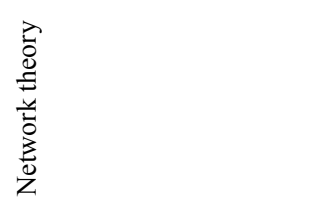 & 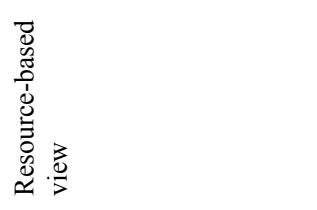 & 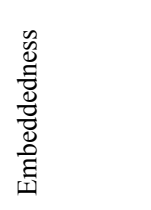 & 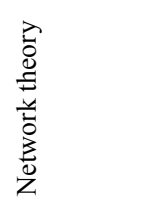 \\
\hline 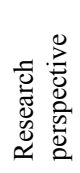 & 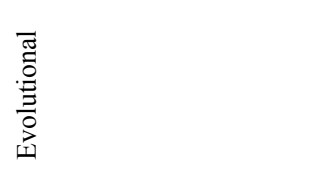 & 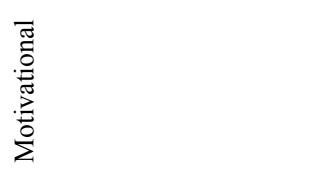 & 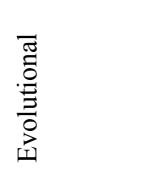 & 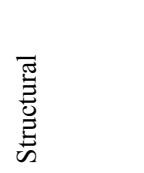 \\
\hline 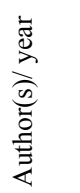 & 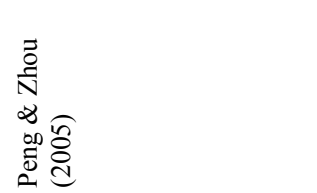 & 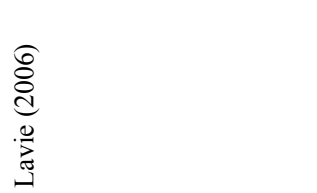 & . & 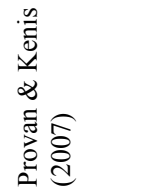 \\
\hline
\end{tabular}




\begin{tabular}{|c|c|c|c|}
\hline 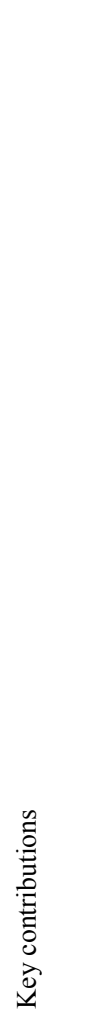 & 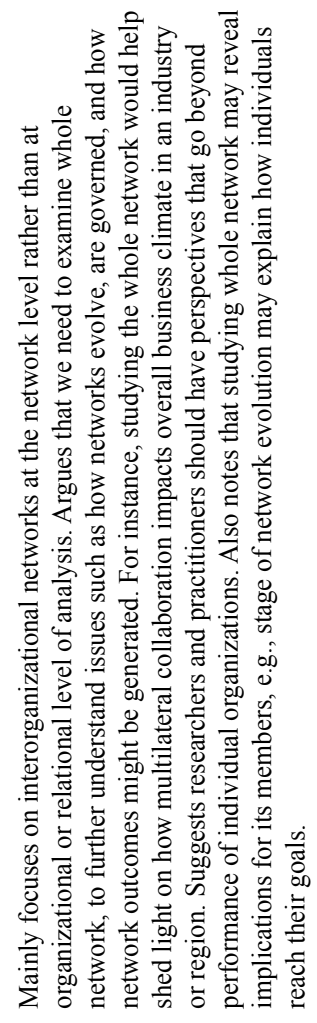 & 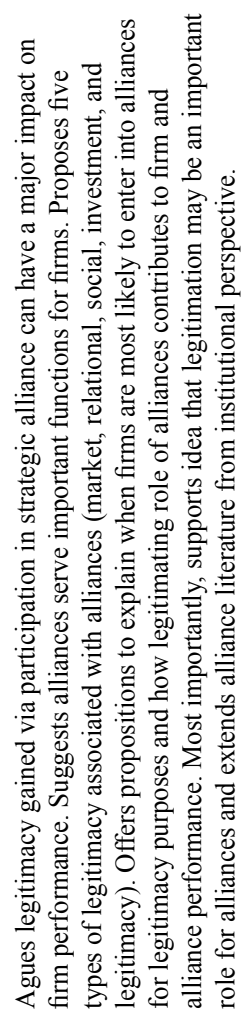 & 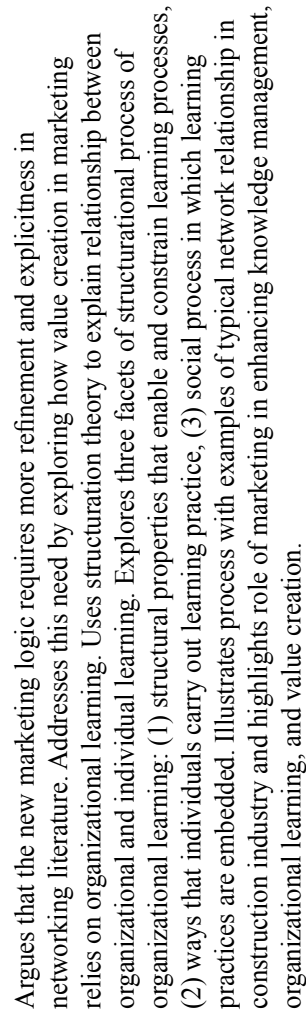 \\
\hline 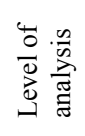 & 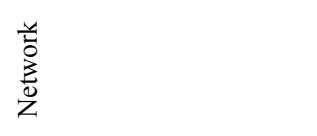 & 声 & 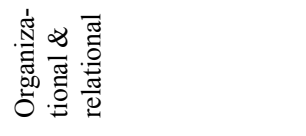 \\
\hline 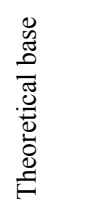 & 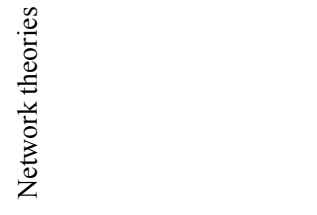 & 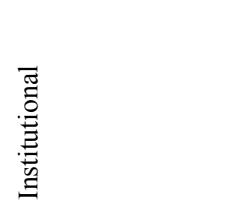 & 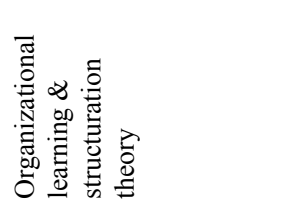 \\
\hline 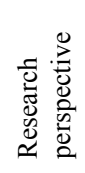 & 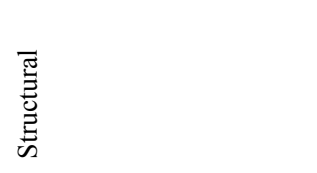 & 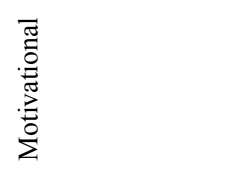 & 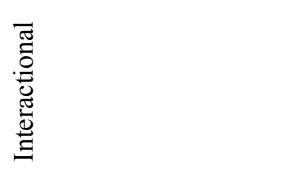 \\
\hline 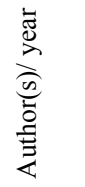 & 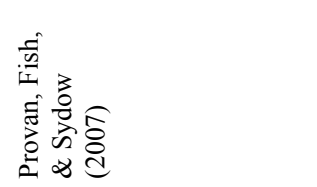 & 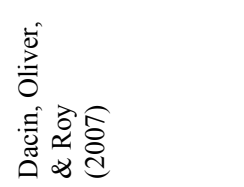 & 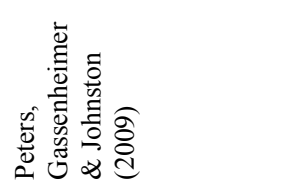 \\
\hline
\end{tabular}




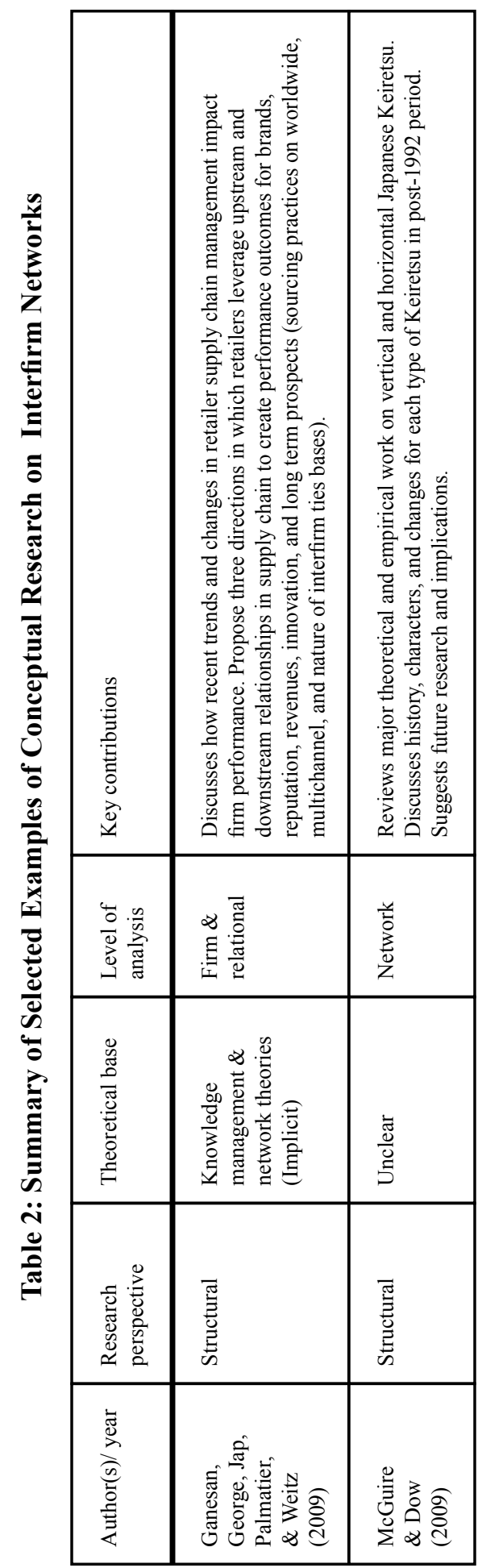




\section{References}

Achrol, R. S. (1997). Changes in the theory of interorganizational relations in marketing: Toward a network paradigm. Journal of the Academy of Marketing Science, 25 (1), 56-71.

Achrol, R. S., \& Kotler, P. (1999). Marketing in the Network Economy. The Journal of Marketing, 63, 146-163.

Baker, W. E., Faulkner, R. R., \& Fisher, G. A. (1998). Hazard of the market: The continuity and dissolution of interorganizational marketing relationships. American Sociological Review, 63(2), 147-177.

Bell, G. G., \& Zaheer, A. (2007). Geography, networks and knowledge flow. Organization Science, 18(6), 955-972.

Bell, D. C., Katsikeas, C. S., \& Robson, M. J. (2010). Does accommodating a selfserving partner in an international marketing alliance pay off? Journal of Marketing, 74(Nov), 77-93.

Bensen, K. J. (1975). The interorganizational network as a political economy. $A d$ ministrative Science Quarterly, 20(2), 229-249.

Borgatti, S. P., \& Foster, P. C. (2003). The network paradigm in organizational research: A review and typology. Journal of Management, 29(6), 991-1013.

Bourdieu, P. (1983). The Forms of Capital, in Soziale Ungleichheiten (Soziale Welt, Sonderheft 2), ed. Reinhard Kreckel, 183-98, Goettingen: Otto Schartz \& Co.

Bourdieu, P. (1986), The Forms of Capital. In: Richardson, J. G. ed. Handbook of Theory and Research for the Sociology of Education. New York: Greenwood Press.

Brass, D., Galaskeiwicz, J. Greve, H. R., \& Tsai, W. (2004). Taking stock of networks and organizations: A multilevel perspective. Academy of Management Journal, 47(6), 795-817.

Burt, R.S. (1997). The contingent value of social capital. Administrative Science Quarterly, 42, 339-365.

Chaskin, R. J., Brown, P., Venkatesh, S., \& Vidal, A. (2001). Building Community Capacity. New York: Aldine de Gruyter.

Coase, R. (1937). The nature of the firm. Economica, 4(16), 386-405. 
Contractor, F. J., \& Lorange, P. (1988). Cooperative Strategies in International Business. Oxford, UK: Elsevier Science, Ltd.

Cook, K. S. (1977). Exchange and power in networks of interorganizational relations. The Sociological Quarterly, 18(1), Special Issue, 62-82.

Coleman, J. S. (1988). Social capital in the creation of human capital. American Journal of Sociology, 94, S95-S120.

Dacin, M. T., Oliver, C., \& Roy, J-P. (2007). The legitimacy of strategic alliances: An institutional perspective. Strategic Management Journal, 28, 169-187.

Dahab, D .J., Gentry, J. W., \& Sohi, R. S. (1996). Interest domination as a framework for exploring channel changes in transforming economies. Journal of Macromarketing, 16(2), 8-23.

Das, T. K., \& Teng, B-S. (2000). A resource-based theory of strategic alliance. Journal of Management, 26(1), 31-61.

Das, T. K., \& Teng, B-S. (2002). Alliance constellations: A social exchange perspective. The Academy of Management Review, 27(3), 445-456.

DiMaggio, P. J,. \& Powell, W. W. (1983). The iron cage revisited: Institutional isomorphism and collective rationality in organizational fields. American Sociological Review, 48, 147-160.

Dyer, J. H. \& Nobeoka, K. (2000). Creating and managing a high performance knowledge sharing network: The Toyota case. Strategic Management Journal, $21,345-67$.

Eccles, R. G., \& Crane, D. B. (1988). Doing Deals: Investment Banks at Work. Boston: Harvard Business School Press.

Eisenhardt, K. M., \& Schoonhoven, C. B. (1996). Resource based view of strategic alliance formation: Strategic and social effects in entrepreneurial firms. Organization Science, 7(2), 136-150.

Fabrizio, C. (2011). Contractual networks, interfirm cooperation and economics growt., Cheltenham, UK: Edward Elgar Publishing, Inc.

Flint, G. D., \& Fleet, D. D. (2011). The competitive cohort: An extension of strategic understanding. Journal of Business Strategies, 28(2), 97-122.

Fombrun, C. J. (1982). Strategies for network research in organizations. The Academy of Management Review, 7(2), 280-291. 
Frels, J. K., Shervani, T. \& Srivastava, R. K. (2003). The intergrated networks model: Explaining resource allocation in network markets. Journal of Marketing, 67(1), 29-45.

Ganesan, S., George, M., Jap, S., Palmatier, R.W., \& Weitz, B. (2009). Supply chain management and retailer performance: Emerging trends, issues, and implications for research and practice. Journal of Retailing, 85(1), 84-94.

Gerlach, M. L. (1992). Alliance Capitalism: The Social Organization of Japanese Business. Berkeley, CA: University of California Press.

Giddens, A. (1984). The Constitution of Society. Outline of the Theory of Structuration. Cambridge: Polity.

Graddy, E. A., \& Chen, B. (2006). Influences on the size and scope of networks for social service delivery. Journal of Public Administration Research and Theory, $16,533-552$.

Granovetter, M. (1973). The strength of weak ties. American Journal of Sociology, 78(6), 1360-1390.

Granovetter, M. (1983). The strength of weak ties: A network theory revisited, in Social Structure and Network Analysis, P.V. Mardsen and Nan Lin (eds), 201-233, Beverly Hills, CA: Sage Publications.

Gu, F. F., Hung, K., \& Tse, D. K. (2008). When does guanxi matter? Issues of capitalization and its dark sides. Journal of Marketing, 72(4), 12-28.

Gulati, R. (1993). The Dynamics of Alliance Formation. Unpublished Doctoral dissertation, Harvard University.

Gulati, R. (1999). Network location and learning: The influence of network resources and firm capabilities on alliance formation. Strategic Management Journal, 20(5), 397-420.

Gulati, R., \& Garguilo, M. (1999). Where do interorganizational networks come from? American Journal of Sociology, 104(5), 1439-93.

Gulati, R., \& Westphal, J. D. (1999). Cooperate or controlling? The effects of CEOboard relations and the content of interlocks on the formation of joint ventures. Administrative Science Quarterly, 44, 473-506.

Gulati, R., Nohria, N., \& Zaheer, A. (2000). Strategic networks. Strategic Management Journal, 21, 203-205. 
Gulati, R., Dialdin, D. A., \& Wang, L. (2002). Organizational networks. In J. A. C. Baum (Ed.), The Blackwell Companion to Organizations: 281-303. Malden, MA: Blackwell.

Holmes, R. M., Bromiley, P., Devers, C. E., Holcomb, T. R., \& McGuire, J. B. (2011). Management theory applications of prospect theory: Accomplishments, challenges, and opportunities. Journal of Management, 37(4), 1069-1107.

Human, S. E., \& Provan, K. G. (2000). Legitimacy building in the evolution of small-firm networks: A comparative study of success and demise. Administrative Science Quarterly, 45, 327-65.

Iacobucci, D. (1996). Networks in Marketing. Thousand Oaks, CA: Sage Publications.

Ingram, P., \& Baum, J. A. C. (1997). Chain affiliation and the failure of Manhattan hotels, 1998-1980. Administrative Science Quarterly, 42, 68-102.

Inzerilli, G. (1990). The Italian perspective: Flexible organization and social management. International Studies of Management and Organization, 20, 6-21.

Jones, C., \& DeFillippi, R. J. (1996). Back to the future in film: Combining industry and self-knowledge to meet career challenges of the 21 st century. Academy of Management Executive, 10(4), 89-104.

Jones, C., Hesterly, W. S., \& Borgatti, S. P. (1997). A general theory of network governance: Exchange conditions and social mechanism. The Academy of Management Review, 22(4), 911-945.

Keister, L. A. (1998). Engineering growth: Business group structure and firm performance in China's transitional economy. American Journal of Sociology, 104, 404-40.

Khanna, T., \& Rivkin, J. W. (2006). Interorganizational ties and business group boundaries evidence from an emerging economy. Organization Science, 17(3), 333-352.

Kogut, B. (1988). Joint ventures: Theoretical and empirical perspectives. Strategic Management Journal, 9(4), 319-332.

Khoja, F. (2010). The triad: Organizational cultural values, practices and strong social intra-firm networks. Journal of Business Strategies, 27(2), 205-228. 
Koka, B. R., \& Prescott, J. E. (2002). Strategic alliance as social capital: A multidimensional view. Strategic Management Journal, 23, 795-816.

Koza, M. P., \& Lewin, A.Y. (1999). The coevolution of network alliances: A longitudinal analysis of an international professional service network. Organization Science 10, 638-53.

Kumar, A, Heide, J. B., \& Wathne, K. H. (2011). Performance implications of mismatched governance regimes across external and internal relationships. Journal of Marketing, 75(March), 1-17.

Larson, A. (1992). Network dyads in entrepreneurial settings: A study of the governance of exchange processes. Administrative Science Quarterly, 397, 76-104.

Larson, A., \& Starr, J. A. (1993). A network model of organization formation. Enterpreneurship Theory and Practice, Winter, 1042-2578.

Lavie, D. (2006). The competitive advantage of interconnected firms: An extension of the resource based view. Academy of Management Review, 31(3), 638-658.

Lazerson, M. (1995). A new phoenix? Modern putting-out in the Modena knitwear industry. Administrative Science Quarterly, 40, 34-59.

Lee, C., Lee, K., \& Pennings, H. M. (2001). Internal capabilities, external networks, and performance: A study on technology-based ventures. Strategic Management Review, 22, 615-640.

Lee, S., Kroll, M. J., \& Walters, B. A. (2011). Stages of corporate governance in transition economies. Journal of Business Strategies, 28(2), 151-176.

Liao, Y. C. (2010). Internal capabilities, external network position, and knowledge creation. Doctoral dissertation, Rensselaer Polytechnic Institute, 2010.

Lin, N. (1999). Building a network theory of social capital. Connections, 22(1), 28-51.

Liu, Y., Atinc, G., \& Kroll, M. (2011). The unique nature of Chinese corporate governance practices. Journal of Business Strategies, 28(1), 29-58.

Lusch, R. F., \& Brown, J. R. (1996). Interdependency, contracting, and relational behavior in marketing channels. Journal of Marketing, 60(October), 19-38.

Madhavan, R., Koka, B. R., \& Prescott, J. E. (1998). Networks in transitions: How industry events (re)shape interfirm relationships. Strategic Management Journal, 19(5), 439-459. 
Mariotti, F. (2011). Knowledge mediation and overlapping in interfirm networks. Journal of Knowledge Management, 15(6), 875-899.

Mariti, P. \& Similey, R. H. (1983). Co-operative agreements and the organization of industry. The Journal of Industrial Economics, 16(4), 437-451.

McEvily, B., \& Zaheer, A. (2004). Architects of trust: The role of network facilitators in geographical clusters. In Trust and Distrust in Organizations, ed. R. Kramer and K. Cook, 189-213. New York: Russell Sage Foundation.

McGuire, J., \& Dow, S. (2009). Japanese keiretsu: Past, present, future. Asia Pacific Journal of Management, 26, 333-351.

Morgan, R. E. (2004). Market-based organizational learning - theoretical reflections and conceptual insights. Journal of Marketing Management, 20, 67-103.

Nygaard A. \& Dahlstrom, R. (2002). Role stress and effectiveness in horizontal alliances. The Journal of Marketing, 66(2), 61-82.

Osborn, R. N., \& Baughn, C. C. (1990). Forms of interorganizational governance for multinational alliances. Academy of Management Journal, 3, 503-519.

Peng, M. W. (2003). Institutional transitions and strategic choice. The Academy of Management Review, 28(2), 275-296.

Peng, M.W., \& Zhou, J. Q. (2005). How network strategies and institutional transitions evolve in Asia. Asia Pacific Journal of Management, 22, 321-336.

Peters, L. D., Gassenheimer, J. B., \& Johnston, W. J. (2009). Marketing and the structuration of organizational learning. Marketing Theory, 9, 341-368.

Pfeffer, J., \& Nowak, P. (1976). Joint ventures and interorganizational interdependence. Administrative Science Quarterly, 21(3), 398-418.

Pisano, G. P. (1989). Using equity participation to support exchange: Evidence from the biotechnology industry. Journal of Law, Economics and Organization, 5(1), 109-126.

Podolny, J. M, \& Page, K. L. (1998). Network forms organization. Annual Review Sociology, 24, 57-76.

Porter, M., \& Fuller, M. B. (1986). Coalitions and Global Strategy. In Michael Porter, ed. Competition in Global Industries, 315-344, Boston: HBS Press. 
Portes, A. (1998). Social capital: Its origins and applications in modern sociology. Annual Review of Sociology, 24, 1-24.

Powell, W. W. (1990). Neither market or hierarchy: Network forms of organization. Research in Organizational Behavior, 12, 295.

Provan, K. G., Isett, K. R., \& Milward, H. B. (2004). Cooperation and compromise: A network response to conflicting institutional pressures in community mental health. Nonprofit and Voluntary Sector Quarterly, 33, 489-514.

Provan, K.G., \& Kennis, P. (2007). Modes of network governance: Structure, management, and effectiveness. Journal of Public Administration Research and Theory, August, 1-24.

Provan, K.G., \& Sebastian, J.G. (1998). Network within networks: Service link overlap, organizational cliques and network effectiveness. The academy of Management Review, 41(4), 453-463.

Putnam, R. D. (2000). Bowling lane: The Collapse and Revival of American Community. New York: Simon \& Schuster.

Reve, T., \& Stern, L. W. (1979). Interorganizational relations in marketing channels. The Academy of Management Review, 4(3), 405-16.

Rindfleisch, A., \& Moorman, C. (2001). The acquisition and utilization of information in new product alliances: A strength of ties perspective. Journal of Marketing, 65, 1-18.

Rowley, T., Behrens, D., \& Krackhardt, D. (2000). Redundant governance structures: An analysis of structural and relational embeddedness in the steel and semiconductor industries. Strategic Management Journal, 21, 369-386.

Scott R.W. (1987). The adolescence of institutional theory. Administrative Science Quarterly, 32, 493-511.

Snow, C. C., Miles, R.E., \& Coleman, H.J., Jr. (1992). Managing 21st century network organizations. Organizational Dynamics, 21(Winter), 5-20.

Stigler, G. J. (1951). The division of labor is limited by the extent of the market. Journal of Political Economy, 59(3), 185-93.

Swaminathan, V., \& Moorman, C. (2009), "Marketing alliances, firm networks, and firm value creation. Journal of Marketing, 73, 52-69. 
Sydow, J., \& Windeler, A. (1998). Organizing and evaluating Interfirm networks: A structurationist perspective on network processes and effectiveness. Organization Science, 9(3), 265-283.

Teisman, G. R., \& Klijn, E. H. (2002). Partnership arrangements: Governmental rhetoric or governance scheme? Public Administration Review, 62, 197-205.

Thorelli, H. B. (1986). Networks: between markets and hierarchies. Strategic Management Journal, 7, 37-51.

Uzzi, B. (1996). The sources and consequences of embeddedness for the economic performance of organizations: The network effects. American Sociological Review, 61, 674-698.

Uzzi, B. (1997). Social structure and competition in interfirm networks: The paradox of embeddedness. Administrative Science Quarterly, 42, 35-76.

Uzzi, B. (1999). Embeddedness in the making financial capital: How social relations and networks benefit firms seeking financing. American Sociological Review, 64(4), 481-505.

Venkatraman, N., \& Lee, C. (2004). Preferential linkage and network evolution: A conceptual model and empirical test in the U.S. video game sector. Academy of Management Journal, 47, 876-892.

Walker, O. C., Jr. (1972). The effects of learning on bargaining behavior. In 1971 Combined Proceedings, F. C. Allvine, ed. Chicago: American Marketing Association, 1, 94-99.

Walker G., Kogut, B., \& Shan, W. (1997). Social capital, structure holes and the formation of an industry network. Organization Science, 8(2), 109-125.

Weiner, B. J., \& Alexander, J. A. (1998). The challenges of governing public-private community health partnerships. Health Care Management Review, 23(2), 39-55.

Westbrock, B. (2010). Natural concentration in industrial research collaboration. The Rand Journal of Economics, 41(2), 351-371.

Williamson, O. E. (1975). Market and hierarchies: Analysis of antitrust implications. London, UK: The Free Press.

Williamson, O. E. (1985). The Economic Institutions of Capitalism: Firms, Markets, Relational Contracting. New York: Free Press. 
Zaheer, A., \& Bell, G.G. (2005). Benefiting from network position: Firm capabilities, structural holes, and performance. Strategic Management Journal, 26, 809-82.

\section{Biographical Sketch of Authors}

Dr. Jie G. Fowler is Assistant Professor of Marketing at Valdosta State University. She received her Ph.D in Marketing from the University of Nebraska-Lincoln. Her recent work focuses on social networks, beauty appeals in advertising, and family dynamics/relationships in the marketplace. Her research appears in Journal of Macromarketing and Advances in Consumer Research.

Dr. Timothy H. Reisenwitz is Professor of Marketing at Valdosta State University. He received his DBA in Marketing from Cleveland State University. His work examines social media, generational cohorts, and academic dishonesty. His research appears in The International Journal of Internet Marketing and Advertising, Journal of Consumer Marketing, Marketing Management Journal, Journal of College Teaching \& Learning, and Academy of Educational Leadership Journal. 